\title{
Chapter 19 \\ Cost, Drivers and Action Against Land Degradation in Senegal
}

\author{
Samba Sow, Ephraim Nkonya, Stefan Meyer and Edward Kato
}

\begin{abstract}
Senegal is facing a major land degradation challenge that poses threat to livelihoods of the rural poor. This study was done to inform policy makers on the cost of inaction and the costs and benefits of taking action against land degradation. The study shows that the annual cost of land degradation on rice, millet and maize - which account for $45 \%$ of cropland area-is US\$103 million, or $2 \%$ of the country's GDP. The on-farm cost of grazing land degradation is about US $\$ 9$ million or $0.1 \%$ of the GDP. The low cost of grazing degradation is a reflection of the low livestock productivity. The cost of land degradation due to Land Use/Cover Change (LUCC) is about US $\$ 0.412$ billion or about $4 \%$ of the GDP. This shows that LUCC accounts for the largest cost of land degradation. The marginal rate of return to investment in restoration of degraded lands is greater than 4-suggesting high returns to taking action against land degradation. Action against land degradation will have far-reaching benefits for the rural poor who heavily depend on natural resources. Senegal has great potential for successfully addressing land degradation. For example, the large number of agricultural extension agents from public and private providers, promoting Integrated Soil Fertility Management (ISFM) practices, Community-Based Forest Management (CBFM) and strengthening public-private partnership could help increase adoption of sustainable land management (SLM) practices. The Dankou Classified Forest investment in awareness creation of ecosystem services led to effective participation of the communities and their participation in protecting it. This demonstrates that awareness creation is a key strategy for ensuring community involvement in protecting natural resources.
\end{abstract}

Keywords Groundthruthing of remote sensing data - Economics of land degradation - Cost of land degradation - Benefits of taking action - Sustainable land management

\author{
S. Sow $(\square)$ \\ Institut National de Pedologie, Dakar, Senegal \\ e-mail: samba_sow@hotmail.fr \\ E. Nkonya $\cdot$ S. Meyer $\cdot$ E. Kato \\ International Food Policy Research Institute, Washington, DC, USA \\ (C) The Author(s) 2016 \\ E. Nkonya et al. (eds.), Economics of Land Degradation \\ and Improvement - A Global Assessment for Sustainable Development, \\ DOI 10.1007/978-3-319-19168-3_19
}




\section{Introduction}

Senegal is one of the countries in sub-Saharan Africa (SSA) that have seen large changes in its economy in the past decade. The country's Gross Domestic Product (GDP) per capita declined from 1982 and bottomed out in 1994 to continue rising through 2012 (World Bank 2012). Between 2003 and 2010, Senegal's expenditure on agriculture increased by $7 \%$ annually. It is one of the 13 SSA countries which have surpassed the Comprehensive Africa Agricultural Development Policy (CAADP) target to spend $10 \%$ of total public expenditure on agriculture (Agriculture for Impact 2014). One of the drivers of such growth has been the political stability of the country and its policies that have been aimed at reducing rural poverty. The strong orientation to agricultural development is explained by the sector's large contribution to the economy and rural employment. The agricultural area (including cropland, forestry) accounts for $49.4 \%$ of the land area and employs $81 \%$ of the rural population (World Bank 2012; DPS 2004). However, the country is facing a major challenge of land degradation. In order to inform policy makers on the costs and benefits of taking action against land degradation, this chapter examines the economics of land degradation. The results will help the country to design appropriate and cost effective approaches to addressing land degradation.

The rest of the report is organized as follows. The next section discusses the severity of land degradation in Senegal. This is followed by key policies and strategies that the country has put in place to achieve its objective of rural development. This is then followed by results based on focus group discussion and other sources of data. The study concludes with policy implications of the results and the way forward for achieving Senegal's objective of preventing and/or reducing land degradation and to restore degraded lands, which is stated in its national action plan that it prepared when it ratified the United Nations Convention to Combat Desertification (UNCCD) in 1995 and more recently (2012) in the National Strategic Investment Framework for SLM.

\section{Extent and Severity of Land Degradation in Senegal}

About $22.2 \%$ of Senegal's population of 13 million live in degraded areas (Le et al. 2014). This is comparable to the share of SSA population affected by land degradation (Ibid). About 9280 ha or $13 \%$ of the agricultural area is degraded (Ibid). However, the Senegal Country Environmental Assessment (World Bank 2008) reports that nearly $65 \%$ of the agricultural land is degraded (Table 19.1). The difference could be due to the type of data used to compute land degradation. Le et al. (2014) use the Normalized Difference Vegetation Index (NDVI) - a vegetation cover index - which may not capture degradation due to soil erosion, salinity and other forms of land degradation that are not well reflected by vegetation cover. 
Table 19.1 Type and extent of land degradation in Senegal, 2001

\begin{tabular}{l|l}
\hline & Share of total land area (\%) \\
\hline Water-erosion & 50.30 \\
\hline Wind-erosion & 1.94 \\
\hline Chemical degradation (e.g. Salinization) & 5.80 \\
\hline Anthropogenic erosion & 7.15 \\
\hline Non-degraded Soils & 34.59 \\
\hline
\end{tabular}

Note There are no reliable recent studies on the severity of land degradation in Senegal. The degradation of land in Senegal increased within the last 30 years. So the actual figures are even worse (World Bank 2008)

Source DAT/USAID/RSI (1985)

Grassland and sparse vegetation were most affected by land degradation (Le et al. 2014). Between 1982 and 2006, $20 \%$ of the grassland area experienced degradation while the sparse vegetation was reduced by $36 \%$ (Ibid). Such loss of vegetation exposes soil to water- and wind-erosion. Additionally, grassland, which covers $12.3 \%$ of the Senegalese land area experiences annual bush fires, a problem, which is common in the bushlands of the Sudanian zones of West Africa (Savadogo et al. 2007). It is estimated that $25 \%-50 \%$ of the Sudanian zone burn every year (Delmas et al. 1991). In Senegal, the area burnt in the period 1997-2012 was 3,141,537 ha, which corresponds to an average of 196,000 ha/year (Centre de Suivi Ecologique 2013).

Land Use/Cover Change (LUCC) is the leading cause of land degradation in SSA since high value biomes are replaced with low value biomes (Nkonya et al. 2015). For example, replacing grasslands with cropland could lead to loss of greater value of ecosystem services. Using classified land use types - could help determine the extent of LUCC-related land degradation. We used the Moderate Resolution Imaging Spectroradiometer (MODIS) landcover data to analyze LUCC. MODIS data used in this study have a resolution of $1 \mathrm{~km}$, which matches the International Geosphere-Biosphere Program (IGBP) land cover classification. Grasslands covered about $72 \%$ of land area in Senegal (see Fig. 19.1) but its extent fell by $21 \%$ in 2009. Shrublands and woodlands covered about 11 and $10 \%$ respectively of land area but the extent of shrublands fell by $32 \%$ while that of woodlands increased by $18 \%$ in 2009.

Forest covered only $0.2 \%$ of land area but its extent increased to a little over $1 \%$ of the land area. The increase occurred mainly in the subhumid area and in the arid and semi-arid zones. Even though MODIS shows an increase in forestand woodlands area, Food and Agriculture Organization (FAO) show moderate deforestation. About 45,000 ha of forest was lost annually in 1990-2000 and about 43,000 ha were lost annually in 2000-2010 (FAO 2011). This is about $0.5 \%$ deforestation rate in both decades, which is the average in SSA (Ibid). The difference between MODIS and FAO forest data is due to the differences in forest definition. FAO defines forest as an area with a minimum coverage of 1 ha, with at least $10 \%$ crown cover and with mature trees at least $2 \mathrm{~m}$ tall (Ibid). The definition explicitly includes 


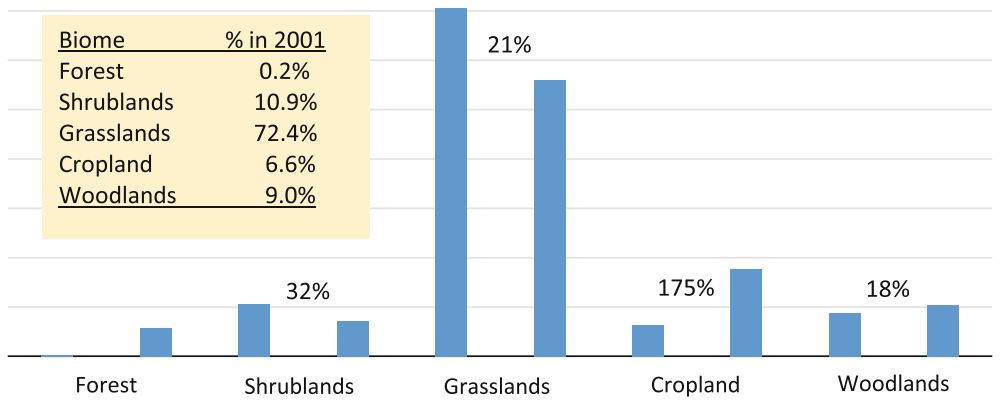

Fig. 19.1 Extent of major biomes in Senegal, 2001 and 2009. Note Definition of forest used by Woody vegetation with height $>2 \mathrm{~m}$ and covering at least $60 \%$ of land area. FAO defines forests as an area with a minimum coverage of 1 ha, with at least $10 \%$ crown cover and with mature trees at least $2 \mathrm{~m}$ tall (FAO 2011). The definition explicitly includes open woodlands, such as those found in the African Sahel and differs from IGBP's definition. Source MODIS data 2010

open woodlands, such as those found in the Sahelian region. This differs from IGBP's (and MODIS) definition that requires a $60 \%$ canopy coverage.

Charcoal burning has contributed to deforestation since local councils lack capacity and legitimacy to enforce tree cutting regulations (Post and Snel 2003). Elite capture by the merchants and village chiefs, circumvent the local governments and operate charcoal production and marketing - leading to land degradation (Ibid). Despite the Decentralization Law of 1996 (see Appendix), which transferred natural resource management to local communities, the central government owns $100 \%$ of forested area (FAO 2005). Such public ownership could be one of the drivers of deforestation. The primary function of forest could also cause deforestation. About $60 \%$ of the total forest area of 8.7 million ha is designed for production and only $18 \%$ is for protection or conservation and the remaining share $(22 \%)$ for multipurpose use (FAO 2005).

Cropland area increased by $175 \%$ in 2009 from its level in 2001. The increase occurred mainly in the groundnut production areas in the arid and semi-arid and subhumid zones. Cropland expansion replaced mainly grasslands and shrublandsa change that amounts to land degradation due to the low ecosystem value of crops compared to grasslands and shrublands (Nkonya et al. 2015).

In addition to land degradation arising from LUCC, Senegal experiences severe salinity problem. It is estimated that 645,000 ha is affected by salinity (DPS 2004). This is about $6.8 \%$ of 9.5 million ha agricultural land (World Bank 2012). Senegal's downstream position of several large rivers and deltas and its largely flat topography leads to poor drainage, which in turn causes salinity (average altitude is less than $50 \mathrm{~m}$ above sea level) (INP 2012) (Fig. 19.2). High seawater tides flood in the coastal area flood, depositing salts on the coastal belt.

Additionally, irrigated areas are poorly drained and this leads to water logging and consequently salinity. The high temperatures for most of the year leads to evaporation - which also contributes to salinity. 


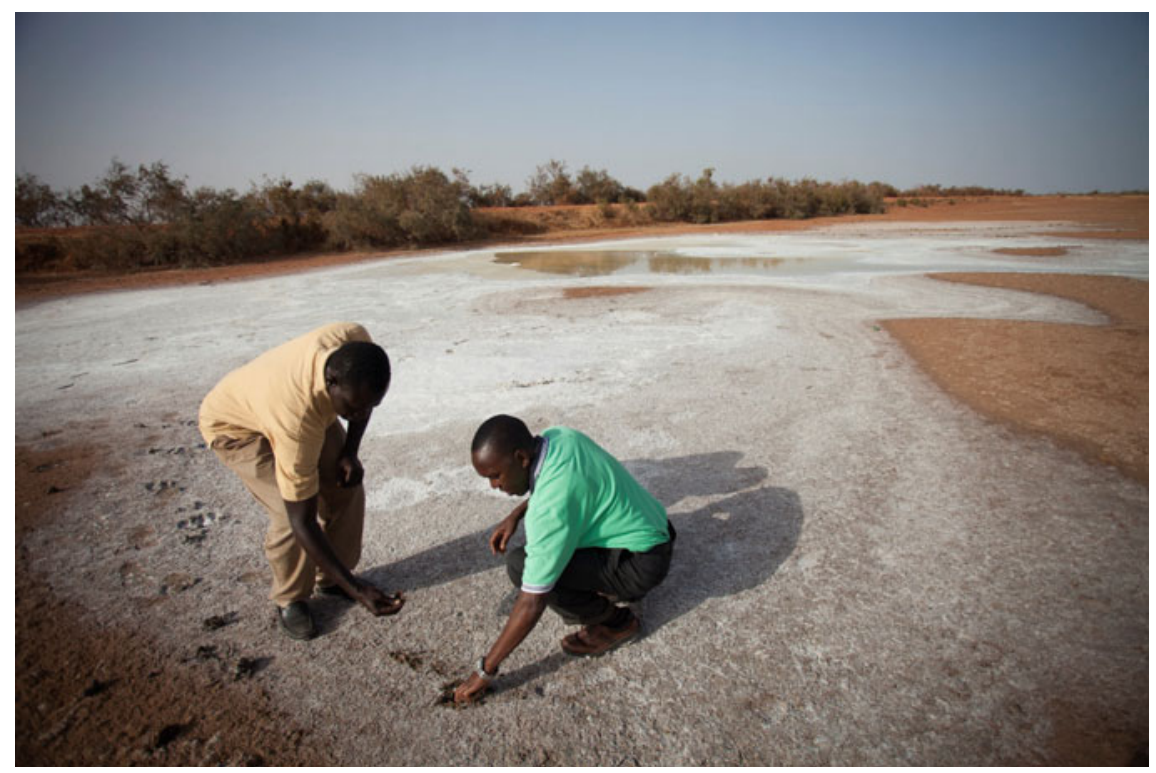

Fig. 19.2 Saline pond in Simal valley (Fatick region). Source Milo Mitchell 2013

Anthropogenic soil erosion was reported to have affected $7.15 \%$ of the total land area and according to Table 19.1 it is the second largest form of land degradation. In the large agricultural areas, like the groundnut basin and Casamance, soil nutrient mining was a major cause of land degradation (World Bank 2008). The application rate of fertilizer in Senegal is among the lowest in SSA. About $1.7 \mathrm{kgN} / \mathrm{ha}$ is applied, a level which is $21 \%$ of the SSA's application rate of $8 \mathrm{kgN} / \mathrm{ha}$ (FAOSTAT 2014). The soil nutrient mining in Senegal is estimated at $41 \mathrm{kgNPK} / \mathrm{ha}$ (Henao and Baanante 2006).

Due to land degradation discussed above and other factors, agricultural value added per worker has remained flat since 1990 (Fig. 19.3) and agricultural production index remained flat since 1990 but grew modestly from 2007 to 2010 and this increase could be attributed to the implementation of special programs to boost production. ${ }^{1}$ The Total Factor Productivity (TFP) grew to the highest level in 1991 and then fell dramatically. Recent recovery of TFP has not yet fully reached its peak in 1991 (Fig. 19.3).

\footnotetext{
${ }^{1}$ In response to the food crisis of 2008, the government initiated GOANA (Great Push Forward for Agriculture, Food, and Abundance) which corresponded to the integration of special programs (Maize Program, Sesame Program etc.) and National Self-Sufficiency Program.
} 

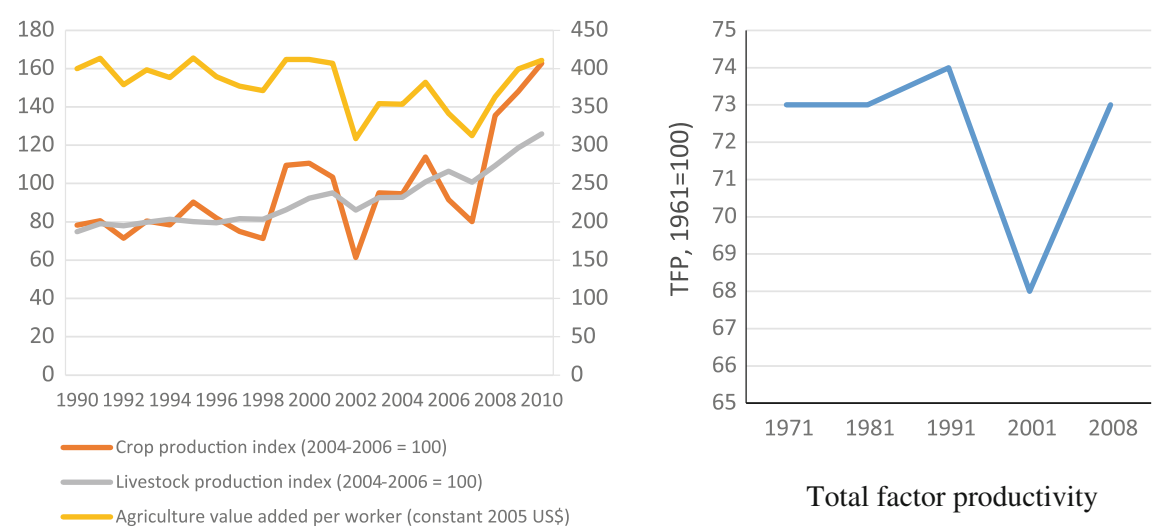

Agricultural \& labor productivity

Fig. 19.3 Agricultural and labor productivity and total factor productivity trends in Senegal

\section{Review of Senegal's Natural Resource and Rural Development Policies and Strategies}

Compared to other SSA countries, Senegal has made significant progress in rural service development and provision. There is a total of 731 agricultural extension service providers of which $68 \%$ were affiliated with NGOs or were private providers. $^{2}$ This puts Senegal among the countries with the smallest number of agricultural households per agricultural extension agent in SSA. On average, each agricultural extension worker served 794 rural households. The corresponding average number of rural household per extension agent in SSA is over 1000 (Davis et al. 2010). DPS (2004) estimated that $58 \%$ of rural households take a maximum of $15 \mathrm{~min}$ to reach a public transportation service. This reflects the significant infrastructure development in Senegal, which ranks the second country in SSAafter South Africa—with high infrastructure development (Fig. 19.4).

However, the country's investment in agricultural research and development as percent of agricultural GDP remains below the New Partnership for Africa's Development (NEPAD) target of $1 \%$ (Beintema and Stads 2011) but its public expenditure in the agriculture sector as percent of total public expenditure exceeded the Maputo declaration target of $10 \%$ (Benin and Yu 2012). As noted earlier however, the country's total factor productivity declined in 2001 and has not yet reached its peak, which it achieved in 1991 (Fig. 19.3).

The government of Senegal has designed a number of policies to prevent land degradation and rehabilitate degraded lands and enhance land productivity. ${ }^{3}$

\footnotetext{
${ }^{2}$ Raw data from the National Agency for Agricultural and Rural Council.

${ }^{3}$ See a summary of policies in Appendix.
} 


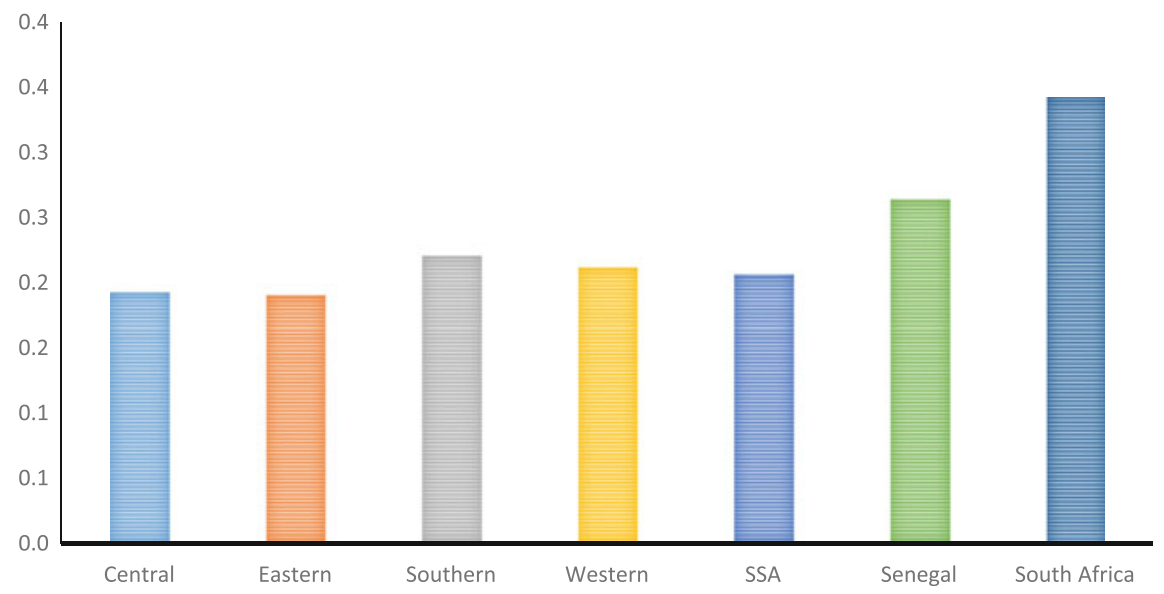

Fig. 19.4 Infrastructure development index. Note Infrastructure development index: 1 = Poorest, 5 = Best. Source Calculated from http://data.worldbank.org/indicator/LP.LPI.INFR.XQ/; http:// www.doingbusiness.org/rankings

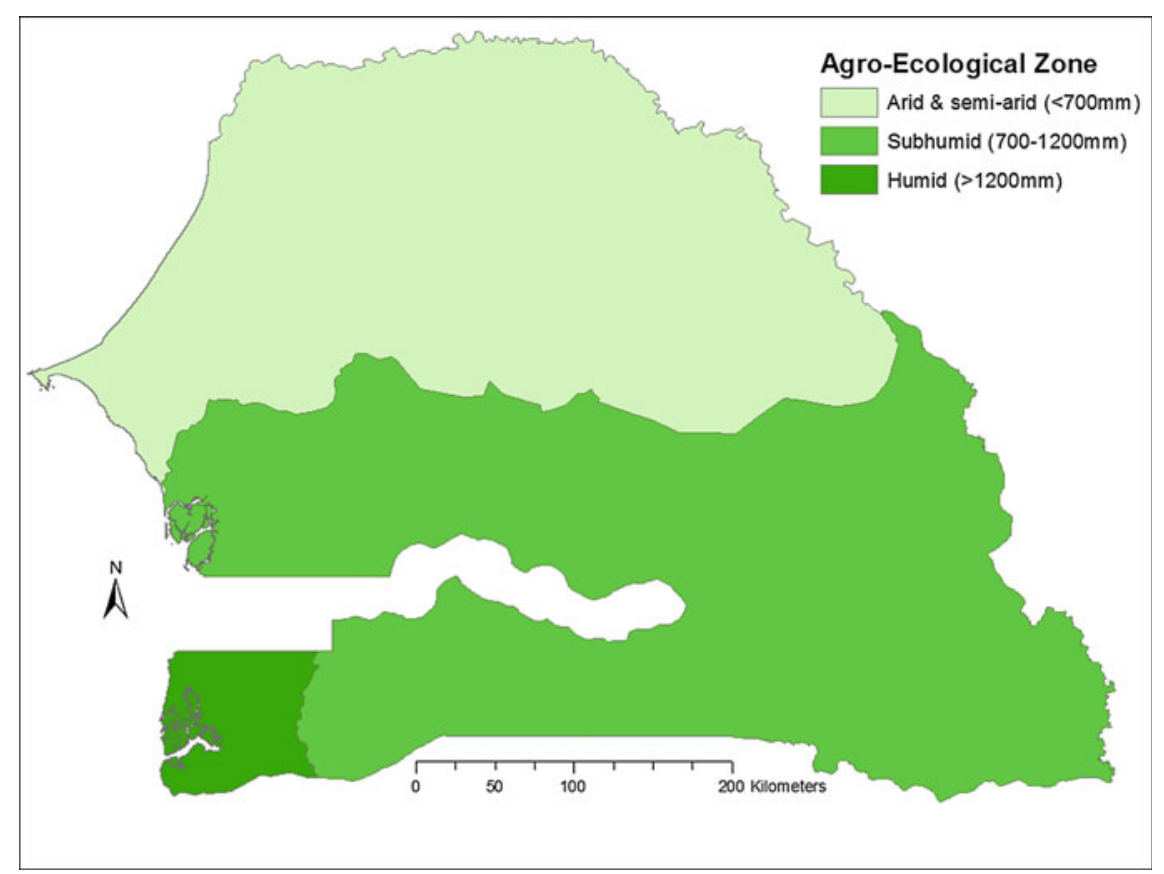

Fig. 19.5 Agroecological zones of Senegal. Source Authors using rainfall data available at Climate Research Unit (CRU), University of East Anglia www.cru.uea.ac.uk/cru/data/precip/ 
Senegal ratified the United Nations Convention to Combat Desertification (UNCCD) in 1995 and has implemented a number of land rehabilitation activities as part of its National Action Plan (NAP). However, the country has been facing challenges in implementing some of NAP activities due to budget constraints.

Senegal enacted the decentralization of natural resource management and other forms of devolution in 1996. Land administration and management was transferred to local governments. As mentioned earlier however, the central government still owns $100 \%$ of the forest resources. As in other countries, the low local capacity of human resource and limited financial resources has contributed to poor performance in land management.

Senegal enacted the Agriculture, Forestry, and Livestock Act (LOASP) in 2004 with an objective of increasing private agricultural investment and to ensure SLM. Despite its good intentions however, implementation of LOASP contributed to land grabbing and deforestation (Stads and Sène 2011). In collaboration with the World Bank, Senegal also implemented the National Framework for Investment into Sustainable Land Management (CNIS/SLM) in 2009. Likewise, the National Institute of Pedology (INP) developed a strategy to coordinate investment to SLM from 2009 to 2012. The project addressed the different forms of land degradation in Senegal by collecting evidence for the severity of soil fertility losses. Best practices were highlighted and a favorable environment implemented for scaling up best management practices (INP 2012).

Through the "Return to Agriculture" Plan (REVA), the government has responded to rural-urban migration by creating better rural economic environment attractive to the youth in rural and urban areas (Stads and Sène 2011). REVA also attracted funding from donors and its review showed considerable impact on reducing rural-urban migration (Resnick 2013). In addition to REVA, Senegal started the Great Push Forward for Agriculture, Food, and Abundance (GOANA) in 2008 with an objective of increasing production of staple foods-namely rice and millet and reducing food importation (Stads and Sène 2011). One of the strategies to implement GOANA was investment in agricultural water management and inputs and strengthening farmer's market and export orientation (Ndione 2009). However, GOANA's impact has not yet been significant (Resnick 2013).

In summary, Senegal has shown significant improvement in rural infrastructure and significant investment in agricultural development. Yet a lot remains to be done to ensure that the policies formulated achieve their stated goals. As of now, most of the policies reviewed have shown limited achievement of their stated goals of reducing land degradation and increasing food production.

\section{Analytical Methods and Data}

Our analytical approach focuses on estimation of cost of land degradation, groundtruthing of satellite data and drivers of adoption of sustainable land management practices. 


\section{Cost of Land Degradation}

We use the approach discussed in detail in Chap. 6, which divides the causes of land degradation into two major groups.

\section{Land Degradation Due to LUCC}

The cost of land degradation due to LUCC is given by

$$
\boldsymbol{C}_{\boldsymbol{L U C C}}=\sum_{i}^{\boldsymbol{K}}\left(\Delta \boldsymbol{a}_{1} * \boldsymbol{p}_{1}-\Delta \boldsymbol{a}_{1} * \boldsymbol{p}_{2}\right)
$$

where $\mathrm{C}_{\mathrm{LUCC}}=$ cost of land degradation due to LUCC; $\mathrm{a}_{1}=$ land area of biome 1 being replaced by biome $2 ; \mathrm{p}_{1}$ and $\mathrm{p}_{2}$ are the Total Economic Value (TEV) of biome 1 and 2, respectively, per unit of area. By definition of land degradation, $\mathrm{p}_{1}>\mathrm{p}_{2}$. This means, LUCC that does not lead to lower TEV is not regarded as land degradation but rather as land improvement or restoration. To obtain the net loss of ecosystem value, the second term in the equation nets out the value of the biome 1 replacing the high value. $\mathrm{i}=$ biome $\mathrm{i}, \mathrm{i}==1,2, \ldots \mathrm{k}$.

\section{Land Degradation Due to Use of Land Degrading Management Practices on a Static Cropland}

We focus on millet, maize and rice to determine the impacts of cropland degradation. Choice of millet is dictated by its extent in Senegal. Millet and cowpeas accounts for 34 and $5 \%$ of cropland area, respectively (FAOSTAT 2014). Millet is grown throughout the country but the crop is predominantly planted on sandy and phosphorus deficient soils (Directorate for Agriculture 2001; Ndiaye 1999) and this results in very low yields. However rotation cropping significantly improves millet yield even on sandy soils. We use DSSAT-CENTURY (Decision Support System for Agrotechnology Transfer) crop simulation model (Gijsman et al. 2002) to determine the impact of SLM practices on crop yield and soil carbon. To capture the long-term impacts of soil fertility management, we simulate the yield for 30 years. We also use results from long-term soil fertility experiments conducted in Senegal to determine the impacts of millet-cowpea rotation versus continuous millet-millet cropping and salinity controlling management practices versus management practices that lead to salinity. 
We use two crop simulation scenarios:

- SLM practices: We consider three types of SLM practices-(a) Integrated Soil Fertility Management (ISFM) — combined use of organic inputs, judicious amount of chemical fertilizer and improved seeds (Vanlauwe and Giller 2006) (b) Millet-cowpea rotation and/or intercropping (c) salinity controlling management practices. The choice of the three SLM practices is largely dictated by empirical evidence of their effectiveness, the type of crops grown in Senegal and the main type of cropland degradation and data availability. Long-term soil fertility experiments have shown that ISFM performs better than the use of fertilizer or organic input alone (Vanlauwe and Giller 2006; Nandwa and Bekunda 1998). Millet-cowpea rotational cropping and intercropping significantly increase crop yield. A long-term experiment conducted in Senegal by Bagayoko et al. (1996) compared different cropping systems of millet and cowpeas between 1991 and 1995 and found that millet yields increased by $24 \%$ and by $26 \%$ for millet and cowpea intercrop and millet-cowpea rotation cropping respectively.

- Business as usual (BAU). The BAU scenario reflects the current management practices practiced by majority of farmers. These could be land degrading management practices or those which are not significantly different from the performance of ISFM.

The cost of land degradation will be determined by comparing the yield differences between the two scenarios. Additionally, long-term soil fertility experiments have shown that, even when using ISFM at recommended levels, yields decline due to decrease of soil organic matter (Nandwa and Bekunda 1998). This is also an indication of land degradation that will be taken into account as shown below.

$$
\left.\mathbf{C L D}=\left(y^{c}-y^{d}\right) P *\left(A-A^{c}\right)+\left(y_{1}^{c}-y_{2}^{c}\right) * A^{c}\right) P-\tau \Delta C O_{2}
$$

where CLD $=$ cost of land degradation on cropland, $\mathrm{y}^{\mathrm{c}}=$ yield with SLM (namely ISFM, crop rotation or salinity-controlling land management), $\mathrm{y}^{\mathrm{d}}$ yield with BAU, $\mathrm{A}=$ total area that remained under cropland in baseline and endline periods, $\mathrm{A}^{\mathrm{c}}=$ cropland area under SLM. $\mathrm{P}=$ price of crop $\mathrm{i} ; y_{1}^{c}, y_{2}^{c}$ are yield under SLM in period 1 and 2, respectively; $\Delta \mathrm{CO}_{2}=$ change in the amount of carbon sequestered under SLM and BAU and $\tau=$ price of $\mathrm{CO}_{2}$ in the global carbon market.

We compute the net carbon sequestration after considering the amount of $\mathrm{CO}_{2}$ emission from nitrogen fertilization and from manure application. Manufacturing, transportation and application one $\mathrm{kg}$ of Nitrogen leads to an emission of $9.3 \mathrm{~kg}$ of $\mathrm{CO}_{2}$-equivalent (Vlek et al. 2004). 


\section{Land Degradation Due to Use of Land Degrading Management Practices on Static Grazing Lands}

We briefly discuss the approach used to assess livestock productivity using beef and milk offtake only. Detailed approach of the analysis is given in Chap. 8. This approach ignores other effects of pasture degradation such as parturition and mortality rate. We also ignore the off-farm impact of grassland degradation such as loss of carbon sequestration and other environmental and ecological services provided by grassland. This means our estimates are conservative.

To determine the anthropogenic land degradation, we identified land degradation as areas where the inter-annual mean NDVI has declined over the historical period of 2001 to 2011 - after netting out the impact of rainfall on NDVI change. Aboveground biomass productivity of grazing lands is then estimated using statistical models which use NDVI to estimate biomass productivity. The cost of land degradation on grasslands is estimated by treating grassland biomass productivity in 2001 and 2011 as baseline and endline, respectively. For details of the approach, please see Chap. 8.

\section{Drivers of Adoption of SLM Practices}

We estimate the drivers of adoption of ISFM, inorganic fertilizer and organic inputs using a probit model specified as follows:

$$
\mathbf{Y}^{*}=\Phi-1(\mathbf{Y})=\mathbf{X} \beta+\varepsilon
$$

where $\mathrm{Y}^{*}$ is a latent variable, such that

$$
Y= \begin{cases}0 & \text { if } Y^{*} \leq 0 \\ 1 & \text { if } Y^{*} \geq 1\end{cases}
$$

$\Phi$ is a cumulative normal distribution with Z-distribution, i.e. $\Phi(Z) \in(0,1)$.

$\mathrm{X}$ is a vector of covariates of drivers of adoption of land management practices and $\beta$ is a vector of the associated coefficients. $X \beta \sim \mathrm{N}(0,1) ; \varepsilon$ is an error term with normal distribution, i.e., $\varepsilon \sim \mathrm{N}(0,1)$.

Choice of the elements of the $\mathrm{X}$ vector in the empirical model is guided by literature and data availability. We use an agricultural household survey conducted in $2011 / 12$.

\section{Cost of Cropland Degradation}

In this section, we estimate the cost of land degradation of major crops in Senegal. As is the case in other SSA countries, adoption rate of SLM practices is low. Figure 19.6 shows that while only $2.5 \%$ of parcels received the most profitable 
Fig. 19.6 The unholy cross: inverse relationship between profit and adoption rate of soil fertility management practices. Source Authors

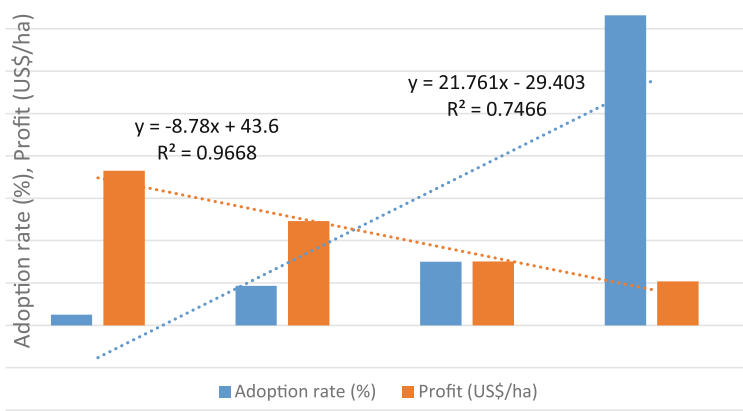

practice-ISFM, i.e., a practice that combines judicious quantities of chemical fertilizer with organic inputs and improved germplasm (Vanlauwe and Giller 2006), about three quarters of parcels did not receive any external inputs - the least profitable management practice. Table 19.2 gives details of adoption rate of the

Table 19.2 Adoption rate of soil fertility management practices in Senegal, 2011/12

\begin{tabular}{|c|c|c|c|c|c|}
\hline & Sample size & Manure only & Fertilizer only & No inputs & ISFM \\
\hline Arid and semi-arid & 16,971 & 15.3 & 9.5 & 72.5 & 2.6 \\
\hline Humid and sub-humid & 6620 & 14.1 & 8.8 & 74.8 & 2.3 \\
\hline \multicolumn{6}{|l|}{ Irrigated rice } \\
\hline Arid and semi-arid & 315 & 7.6 & 86.0 & 2.5 & 3.8 \\
\hline Humid and sub-humid & 22 & 4.6 & 18.2 & 77.3 & 0.0 \\
\hline \multicolumn{6}{|l|}{ Rainfed rice } \\
\hline Arid and semi-arid & 43 & 16.3 & 13.9 & 55.8 & 13.9 \\
\hline Humid and sub-humid & 2001 & 21.9 & 4.5 & 72.4 & 1.2 \\
\hline \multicolumn{6}{|l|}{ Groundnuts } \\
\hline Arid and semi-arid & 6935 & 11.7 & 8.1 & 78.7 & 1.6 \\
\hline Humid and sub-humid & 1643 & 4.2 & 10.2 & 84.2 & 1.3 \\
\hline \multicolumn{6}{|l|}{ Millet } \\
\hline Arid and semi-arid & 5527 & 21.2 & 8.0 & 67.8 & 3.0 \\
\hline Humid and sub-humid & 933 & 13.7 & 7.9 & 76.4 & 1.9 \\
\hline \multicolumn{6}{|l|}{ Sorghum } \\
\hline Arid and semi-arid & 1057 & 8.8 & 3.2 & 87.3 & 0.7 \\
\hline Humid and sub-humid & 711 & 9.7 & 4.8 & 84.4 & 1.1 \\
\hline \multicolumn{6}{|l|}{ Maize } \\
\hline Arid and semi-arid & 922 & 24.1 & 18.1 & 48.1 & 9.8 \\
\hline Humid and sub-humid & 818 & 18.7 & 14.8 & 60.5 & 6.0 \\
\hline \multicolumn{6}{|l|}{ Cowpea } \\
\hline Arid and semi-arid & 1363 & 14.7 & 1.6 & 83.4 & 0.4 \\
\hline Humid and sub-humid & 112 & 7.1 & 2.7 & 90.2 & 0.0 \\
\hline
\end{tabular}

Sources Adoption rates: Computed from raw data of the Agricultural survey (Enquête Agricole) $(2011 / 12)$ 
three management practices across agroecological zones (AEZ) (Fig. 19.5) and crops and all consistently show the same pattern-lowest adoption rate for the most profitable and highest adoption for the least profitable land management. The inverse relationship between profitability and adoption rate of land management suggests there are challenges which hamper farmers from adopting the most profitable land management practices. Of interest is the greater adoption of ISFM in arid and semi-arid lands (ASAL) than in humid and sub-humid zone for almost all crops. This could be an attempt of farmers in the ASAL to increase soil carbon and consequently reduce production risks.

The low adoption of sustainable land management practices lead to land degradation. DSSAT simulation results show that cost of land degradation for maize and rice, which respectively account for only 5 and $6 \%$ of the cropland of 2.6 million ha of cropland (FAOSTAT 2014) is about 2007 US\$114.52 million (Table 19.3) or $1 \%$ of the 2007 GDP of US\$ 11.285 billion (World Bank 2013). The results have important implications on rice, a crop that is currently receiving significant attention as its consumption is increasing-leading to large importation. To contribute to country's goal of food self-sufficiency, steps need to be taken to address land degradation on rice and other crops.

Cowpea-millet rotation increased millet yields by $24 \%$ and by $26 \%$ for millet and cowpea intercrop-cowpea rotation (Table 19.4). Crop rotation improves soil fertility through symbiotic nitrogen fixation. Additionally cowpea does not mine soil phosphorus reserves. Thus, after cowpea cultivation, soils have amounts of nitrogen and phosphorus that leads to higher millet yield. According to recent work at the Center for Studies and Research (CERAAS), high nitrogen content in the soil also promotes good soil moisture. The results are consistent with Gueye (1992) who

Table 19.3 Cost of cropland degradation due to use of soil fertility mining practices

\begin{tabular}{|c|c|c|c|c|c|c|}
\hline \multirow[t]{2}{*}{ Crop } & \multirow[t]{2}{*}{ Technology } & \multicolumn{2}{|c|}{ Average yield } & \multirow{2}{*}{$\begin{array}{l}\text { Percent } \\
\text { change }\end{array}$} & \multirow{2}{*}{$\begin{array}{l}\text { ISFM adoption } \\
\text { rate }(\%)\end{array}$} & \multirow{2}{*}{$\begin{array}{l}\text { Cost of land } \\
\text { degradation } \\
\text { (US\$ million) }\end{array}$} \\
\hline & & $\begin{array}{l}\text { First } \\
10 \text { years }\end{array}$ & $\begin{array}{l}\text { Last } \\
10 \text { years }\end{array}$ & & & \\
\hline \multirow{2}{*}{$\begin{array}{l}\text { Irrigated } \\
\text { rice }\end{array}$} & ISFM & 7.5 & 6.2 & 17.4 & 3.8 & 12.45 \\
\hline & BAU & 6.7 & 5.1 & 24.6 & & \\
\hline \multirow{2}{*}{$\begin{array}{l}\text { Rainfed } \\
\text { rice }\end{array}$} & ISFM & 7.8 & 4.9 & 21.4 & 13.9 & 48.53 \\
\hline & BAU & 7.7 & 4.8 & 35.0 & & \\
\hline \multirow{2}{*}{$\begin{array}{l}\text { Rainfed } \\
\text { maize }\end{array}$} & ISFM & 2.4 & 1.9 & 36.9 & 9.8 & 41.78 \\
\hline & BAU & 1.9 & 1.3 & 38.1 & & \\
\hline $\begin{array}{l}\text { Total } \\
\text { cost }\end{array}$ & & & & & & 102.76 \\
\hline \multicolumn{6}{|c|}{ Total cost of rice and maize cropland degradation as $\%$ of GDP } & $1 \%$ \\
\hline
\end{tabular}

Notes Percent change $=\frac{y_{1}-y_{2}}{y_{1}} * 100$

$B A U$ Business as usual-farmer practice

Average harvested area of crops are (with corresponding area in brackets): Rice (116,226 ha) and maize (154,347 ha) (Source FAOSTAT 2014). Crop prices: Rice (US\$656/ton) and maize US \$543/ton; Source Calculated from DSSAT simulation results (see Nkonya et al. 2015). Adoption rate of soil fertility management practices: Agricultural survey (2011/12) 
Table 19.4 Impact of millet-cowpea cropping systems on millet yield in Senegal

\begin{tabular}{l|l|l|l|l|l|l|l}
\hline & 1991 & 1992 & 1993 & 1994 & 1995 & Average & \% change \\
\cline { 2 - 10 } & \multicolumn{7}{|l}{ Millet yield (tons/ha) } \\
\hline Cowpea-pearl millet rotation & 1.4 & 2.4 & 1.4 & 1.6 & 2.1 & 1.8 & 24 \\
\hline Intercrop-pearl millet rotation & 1.2 & 2.2 & 1.2 & 1.3 & 1.6 & 1.5 & 4 \\
\hline Continuous pearl millet-control & 1.1 & 2.0 & 1.1 & 1.3 & 1.6 & 1.4 & \\
\hline Continuous intercrop & 0.8 & 1.5 & 0.9 & 1.0 & 1.4 & 1.1 & -20 \\
\hline Pearl Millet-Intercrop Rotation & 1.4 & 2.4 & 1.4 & 1.6 & 2.1 & 1.8 & 26 \\
\hline
\end{tabular}

Source Bagayoko et al. (1996)

found greater millet yield in cowpea-millet rotation cropping. Based on Bagayoko et al. (1996) results, Table 19.5 shows that millet continuous cropping leads to a national loss of about US\$ 77 million per year.

Salinity affects mainly rice production in the Sine-saloum and Casamance river basins. The recommended practice for addressing salinity is flushing and good drainage. Demonstration plots showing the proper management practices for addressing salinity was carried out by the Project to Support Local Small-Scale Irrigation (PAPIL). The long-term PAPIL demonstration included one treatments that included the recommended practice of addressing salinity - flushing salinity and proper drainage and a control treatment, which was the farmer practice of poor drainage and no flushing. The yield of treatment plots was 2.8 tons/ha while the yield on control plots was only 1.4 tons in the arid and semi-arid zone (Table 19.5). The corresponding cost of salinity is about US\$22 million per year (Table 19.5).

Table 19.5 Cost of continuous cropping and salinity on millet and rice cropland

\begin{tabular}{l|l|l|l|l|l}
\hline & $\begin{array}{l}\text { BAU Yield } \\
\text { (t/ha) }\end{array}$ & $\begin{array}{l}\text { SLM Yield } \\
\text { (t/ha) }\end{array}$ & $\begin{array}{l}\text { Cost of land } \\
\text { degradation, } \\
\text { US\$/ha }\end{array}$ & $\begin{array}{l}\text { Total area } \\
\text { affected by } \\
\text { salinity } \\
\text { (ha) }\end{array}$ & $\begin{array}{l}\text { Total cost of } \\
\text { land } \\
\text { degradation } \\
\text { (US\$ million) }\end{array}$ \\
\hline $\begin{array}{l}\text { Cereal-legume } \\
\text { cropping } \\
\text { system }\end{array}$ & $\begin{array}{l}\text { Continuous } \\
\text { millet } \\
\text { cropping }\end{array}$ & $\begin{array}{l}\text { Millet-cowpea } \\
\text { rotation }\end{array}$ & & & \\
\hline Millet & 1.43 & 1.78 & 258 & 402,813 & 77.39 \\
\hline Salinity-rice & $\begin{array}{l}\text { With } \\
\text { salinity }\end{array}$ & $\begin{array}{l}\text { Without } \\
\text { salinity }\end{array}$ & & & \\
\hline $\begin{array}{l}\text { Humid and } \\
\text { subhumid zone }\end{array}$ & 1.8 & 2.7 & 591 & 7384 & 4.37 \\
\hline $\begin{array}{l}\text { Arid and } \\
\text { semi-arid zone }\end{array}$ & 1.4 & 2.8 & 834 & 20,982 & 17.49 \\
\hline $\begin{array}{l}\text { Total Cost of } \\
\text { LD }\end{array}$ & & & & & 99.25 \\
\hline
\end{tabular}

Source Authors 


\section{Cost of Land Degradation on Grasslands}

While pasture covers $56,500 \mathrm{~km}^{2}$ or $69.3 \%$ of Senegalese land area, it accounts for only $14.8 \%$ of the Senegal's GDP and $37.3 \%$ of the agricultural GDP (FAO 2005). This is due to the low livestock productivity in the country. Senegal lost about 2007 US\$ 9 million annually due to degradation grazing biomass or about $0.1 \%$ of the 2007 GDP (Table 19.6). While the small cost of land degradation underscores the low livestock productivity, it signifies the need to address degradation of grazing lands to take advantage of the increasing national and international demand for livestock products.

\section{Cost of Land Degradation Due to Land Use/Cover Change}

The costs related to land degradation as a result of LUCC for Senegal are reported in Table 19.7. The LUCC data used in the analysis is reported in Fig. 19.7. Using the TEV approach (see Nkonya et al. 2015), the annual cost of land degradation due to LUCC is estimated to be about US\$0.733 billion. The cost is highest in the subhumid area - which experienced the largest cropland expansion into grasslands and shrublands (Fig. 19.7). However if we only consider the provisioning services and other local benefits, the cost of land degradation is US\$0.412 billion or about $4 \%$ of the GDP. Table 19.8 summarizes the annual cost of land degradation for LUCC and cropland. Land degradation due to LUCC is about $7 \%$ of the GDP and the cost of salinity, continuous cropping and soil fertility mining for the selected crops (maize, rice and millet) is only about $2 \%$ of the GDP. The cost of grazing biomass degradation is US\$9 billion or $0.1 \%$ of the GDP. The low cost of grazing biomass degradation is largely due to the low livestock productivity. However, the local impact of land degradation on cropland on human welfare of the Senegalese population is much greater than its small value shown since crops provide provisioning services that directly affect welfare.

As expected the cost of action to address LUCC-related land degradation is much smaller than the cost of inaction. Over the 30 year planning horizon, the cost of action as percent of cost of inaction ranges from $22 \%$ in the humid areas to $25 \%$ in the ASAL (Table 19.7). Accordingly, the returns to taking action against

Table 19.6 On-farm cost of land degradation on grasslands in Senegal

\begin{tabular}{l|l|l|l}
\hline \multirow{2}{*}{ AEZ } & \multicolumn{1}{|l|}{ Milk } & Meat & Total cost \\
\cline { 2 - 4 } & \multicolumn{2}{|l}{ 2007 US\$ million } \\
\hline Tropic-warm/semi-arid & 0.141 & 0.008 & 0.149 \\
\hline Tropic-warm/arid & 0.153 & 0.012 & 0.165 \\
\hline Tropic-warm/sub-humid & 8.554 & 0.566 & 9.120 \\
\hline Total & 8.847 & 0.586 & 9.434 \\
\hline Percent of 2007 GDP & 0.08 & 0.01 & 0.08
\end{tabular}

Source Authors 
Table 19.7 Cost of land degradation due to LUCC, action and inaction in Senegal

\begin{tabular}{|c|c|c|c|c|}
\hline & $\begin{array}{l}\text { Arid and } \\
\text { semi-arid }\end{array}$ & Sub-humid & Humid & Total \\
\hline & \multicolumn{4}{|c|}{2007 US\$ billion } \\
\hline Total annual cost of land degradation & 0.238 & 0.482 & 0.013 & 0.733 \\
\hline Total annual cost-local ES loss only & 0.122 & 0.285 & 0.006 & 0.412 \\
\hline Cost of action 1 st 6 years & 3.30 & 6.67 & 0.23 & 10.19 \\
\hline Cost of action 30 years & 3.32 & 6.70 & 0.23 & 10.24 \\
\hline Opportunity cost & 3.22 & 6.55 & 0.22 & 9.99 \\
\hline Cost of inaction & 14.57 & 30.32 & 0.91 & 45.80 \\
\hline \multirow{2}{*}{$\begin{array}{l}\text { Marginal rate of returns to action } \\
\text { against LUCC land degradation }\end{array}$} & 4.4 & 4.5 & 4.0 & 4.5 \\
\hline & \multicolumn{4}{|l|}{ Percent } \\
\hline $\begin{array}{l}\text { Zonal contribution to cost of land } \\
\text { degradation as } \% \text { of total }\end{array}$ & 32 & 66 & 2 & 100 \\
\hline Opportunity cost as $\%$ of cost of action & 97 & 98 & 98 & 98 \\
\hline Cost of action as $\%$ of cost of inaction & 23 & 22 & 25 & 22 \\
\hline
\end{tabular}

Source Authors

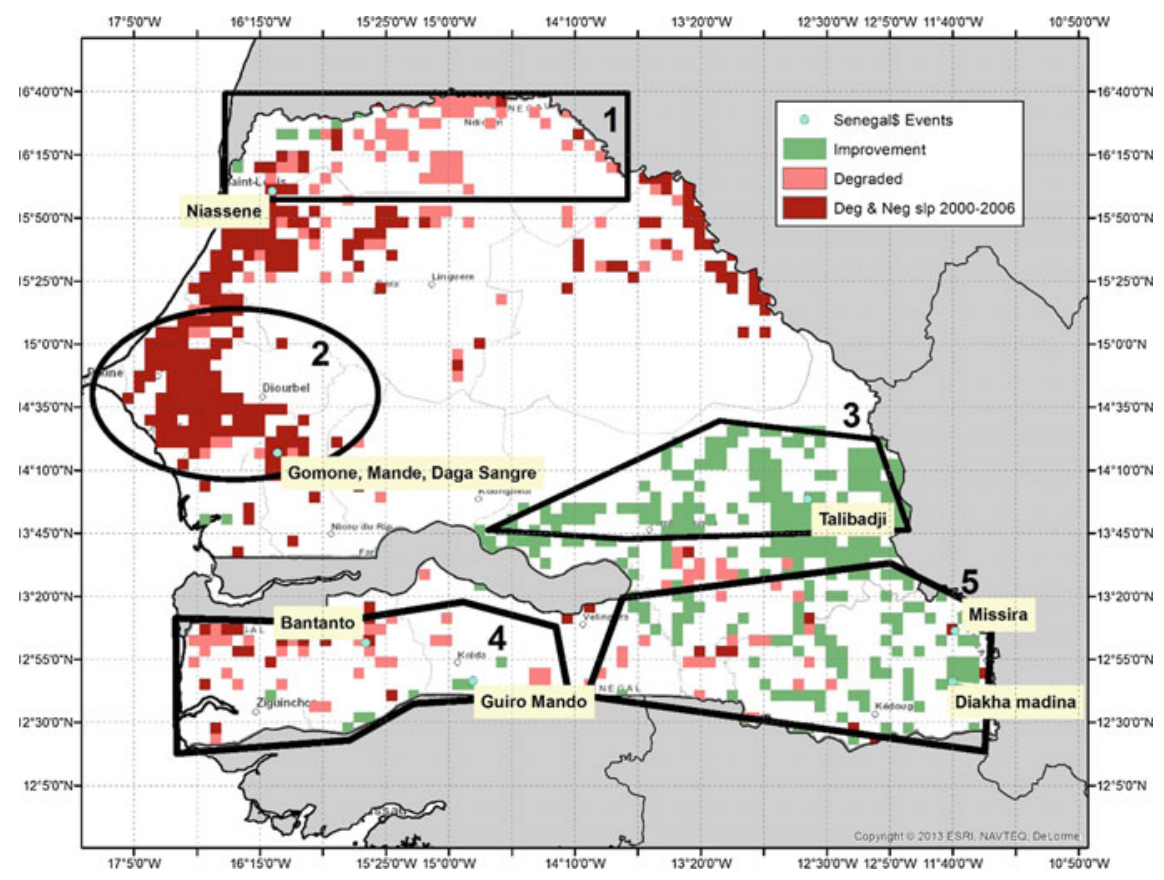

Fig. 19.7 Case study communities selected for FGD and groundtruthing 
Table 19.8 Summary of annual cost of land degradation

\begin{tabular}{l|l|l|l}
\hline Type of land degradation & Source & Annual cost (US\$ million) & \% of GDP \\
\hline LUCC & Table 19.5 & 733 & 6.5 \\
\hline LUCC-local tangible benefits & Table 19.5 & 412 & 3.7 \\
\hline Soil fertility mining-maize and rice & Table 19.2 & 103 & 0.9 \\
\hline Salinity-irrigated rice & Table 19.5 & 22 & 0.2 \\
\hline Continuous cropping-millet & Table 19.5 & 77 & 0.7 \\
\hline Degradation of grazing biomass & Table 19.6 & 9 & 0.1 \\
\hline Gross total & & 944 & 8.4 \\
\hline Total-local ES loss only & & 623 & 5.5 \\
\hline
\end{tabular}

Source Authors

LUCC-related land degradation is high. The returns for every dollar invested to rehabilitate LUCC-related land degradation is about US\$4. However, given that a large share of the benefits of rehabilitation of LUCC-related are off-site, land users may not take action since their decision making is driven by on-farm benefits. Thus, an important question is to examine the perception of land users on LUCC and other forms of land degradation and to analyze their response to land degradation. We use Focus Group Discussions (FGD) to examine the community perception on land degradation and steps they take to address it.

\section{Focus Group Discussion Results}

FGD were conducted in seven Senegalese communities shown in Fig. 19.7. The communities were selected to cover AEZ and to represent areas that Le et al. (2014) showed land improvement or land degradation in each AEZ (see Table 19.9). Approximately 10-20 community members participated in the FGD.

Participants were purposively selected to represent old people who could give informed perception on land use change over the 30 year reference period; women, the youth, local government leaders, crop producers, livestock producers, people

Table 19.9 Names, agroecological zone and status of land degradation or improvement of the selected communities

\begin{tabular}{l|l|l}
\hline Community & Agroecological zone & Status of land degradation and improvement \\
\hline Diakha Madina & Sub-humid & Improvement \\
\hline Missira & Sub-humid & Improvement \\
\hline Guiro Mandou & Subhumid & Degradation \\
\hline Bantanto & Semi-arid & Degradation \\
\hline Gomone & Semi-arid & Severe degradation \\
\hline Niassene & Arid & Severe degradation \\
\hline Talibadji & Semi-arid & Improvement \\
\hline
\end{tabular}


who earn their livelihoods from forest and other non-agricultural terrestrial biomes, and customary leaders. Such a diverse groups afforded a rich discussion on ecosystem value and their change from 1982 to 2012.

Groundtruthing remote sensing data was done by asking FGD members to show the LUCC and land degradation or improvement of the major biomes which have occurred in the community over a 30 year period (1982-2012). Groundtruthing helps to determine reliability of the satellite data used in this report.

\section{Change in the Importance of Ecosystem Services and Drivers of Change}

The members of the FGD's stated their perception of the importance of ecosystem services provided by different biomes in 1982 and in 2012. Figure 19.8 summarizes the trend of importance and the communities' awareness of the ecosystem services. As expected, awareness of the provisioning is the highest followed by that of cultural services. Awareness of the regulating and support services is the lowest. The degree of awareness implies the priority that the ecosystem services receive from communities in their decision making process. Communities perceived that importance of all three major types of ecosystem services in 2012 decreased from their levels in 1982 (Fig. 19.8). Importance of the regulating and support services experienced the steepest decline while that of cultural services experienced the smallest loss. The major reason driving the decline in importance of the regulating services is climate change, which was mentioned by four of the six communities.

Soil erosion was mentioned by three of the six communities as the driver of declining regulating services. The communities argued that soil erosion decreased nature's capacity to fight pests and diseases as well as water quality. Change in spiritual values was the major driver of declining cultural values of ecosystem services. Such trend is expected as modernism among young people erodes cultural

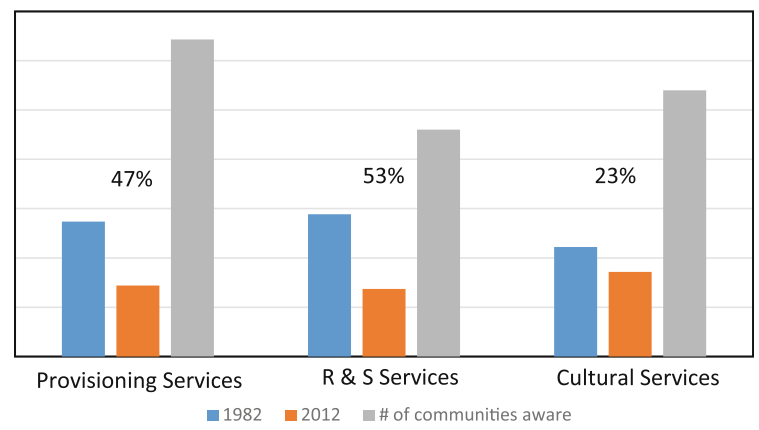

Fig. 19.8 Awareness of ecosystem services and summary of trend of their importance. Notes Ecosystem importance index: 1 = Not important, 2 = Important, 3 = Very important. Percentage above histograms show the \% loss of Ecosystem Services 
values (Inglehart and Welzel 2005). Three communities reported an increase in importance of ecotourism and other three reported a fall. The driver of increase in importance of ecotourism was promotion of tourism by the government. Land degradation and changing cultural beliefs were cited as the major cause of falling importance of ecotourism.

A detailed analysis of trend of importance of specific ecosystem services is given in Fig. 19.9. With the exception of two cultural services (ecotourism and knowledge), importance of all other types of ecosystem services declined in 2012 from their levels in 1982 (Fig. 19.9). Six out of the seven communities reported a declining importance for crop provisioning services. Six communities reported land degradation as the major driver of declining importance of the crop provisioning services. Figure 19.9 shows that importance of provisioning services changed from very important in 1982 to not important in 2012. Increasing salinity and declining soil fertility were explicitly mentioned in Bantanto as drivers of such fall in importance.

The provisioning services from livestock shows an interesting pattern. Three of the seven communities reported increasing importance of provisioning services from livestock (Table 19.10). All three communities (Gomone, Niassene and Talibadji) are in the ASAL zone (Table 19.9), where livestock production is an important sector. Consistent with Kearney (2010), increasing demand for livestock products is reported as the major driver of the increasing importance of livestock provisioning services. The increasing importance of livestock provisioning services reflects farmers' response to market signals. The results are also supported by the increasing livestock population and production of animal products in Senegal (FAO 2005). Accordingly, consumption of animal products has increased (FAO 2005).

The government livestock development program in Gomone could have contributed to increasing importance of livestock since community members reported that the intervention contributed to higher livestock productivity. Theft and diseases

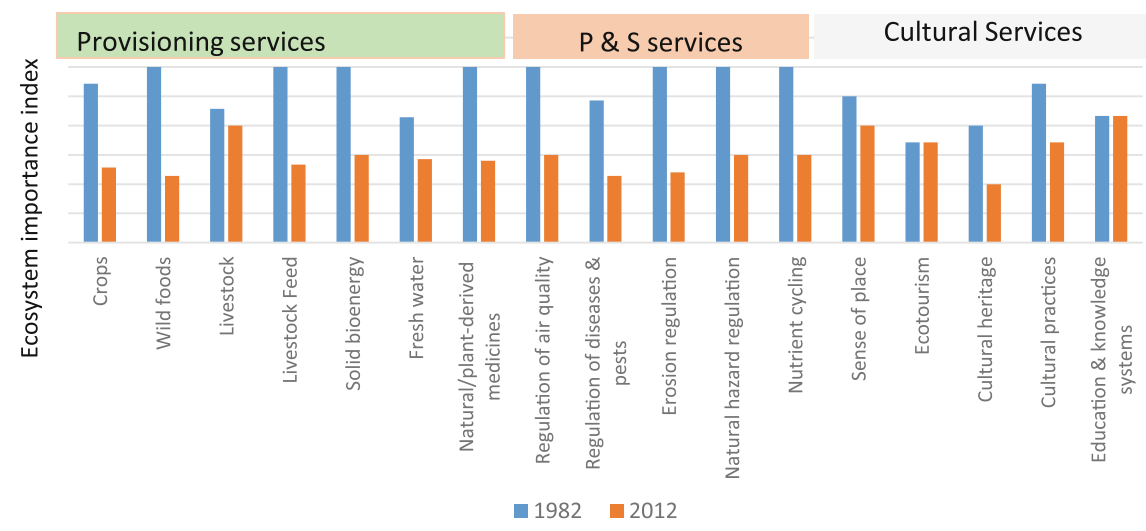

Fig. 19.9 Ecosystem services and trend of their importance. Notes Ecosystem importance index: $1=$ Not important $2=$ Important $3=$ Very important. $\mathrm{R} \& \mathrm{~S}$ services $=$ regulating and support services 
Table 19.10 Trend of importance of provisioning services from livestock

\begin{tabular}{|c|c|c|c|c|}
\hline Community & Trend & Reasons of trend & & \\
\hline Bantanto & Decrease & Theft & Diseases & \\
\hline $\begin{array}{l}\text { Diakha } \\
\text { Madina }\end{array}$ & Decrease & Diseases & & \\
\hline Gomone & Increase & $\begin{array}{l}\text { Livestock development } \\
\text { project }\end{array}$ & & \\
\hline $\begin{array}{l}\text { Guiro } \\
\text { Mandou }\end{array}$ & Decrease & Theft & & \\
\hline Missira & Decrease & Less extension services & & \\
\hline Niassene & Increase & $\begin{array}{l}\text { Greater demand of } \\
\text { livestock products }\end{array}$ & $\begin{array}{l}\text { Greater awareness of } \\
\text { livestock importance }\end{array}$ & $\begin{array}{l}\text { Greater } \\
\text { income }\end{array}$ \\
\hline Talibaldji & Increase & $\begin{array}{l}\text { Changing market } \\
\text { supply }\end{array}$ & $\begin{array}{l}\text { Greater awareness of } \\
\text { livestock importance }\end{array}$ & \\
\hline
\end{tabular}

Source Focus Group Discussion 2014

were the two major causes of decreasing importance of livestock provisioning services. Cattle theft remains a major problem in Senegal and the "safeguard livestock operations" is among government efforts to address it (Stads and Sène 2011). Contrary to MODIS data, which shows an increase in forest area, forest area decreased in six of the seven communities (Fig. 19.10). Diakha Madina and Talibadji, both of which have the largest areas under forest, forested areas declined in all villages. This explains the corresponding reduction in importance of forest product provisioning services (e.g. solid bioenergy) reported in Fig. 19.9.

A follow up question on trend of importance of ecosystem services was on how the communities were responding to unfavorable and favorable trends. The section below reports actions taken by communities in response to changes in ecosystem services. Emphasis is placed on actions that have been successful and those which have not worked and the reasons behind success or failure.

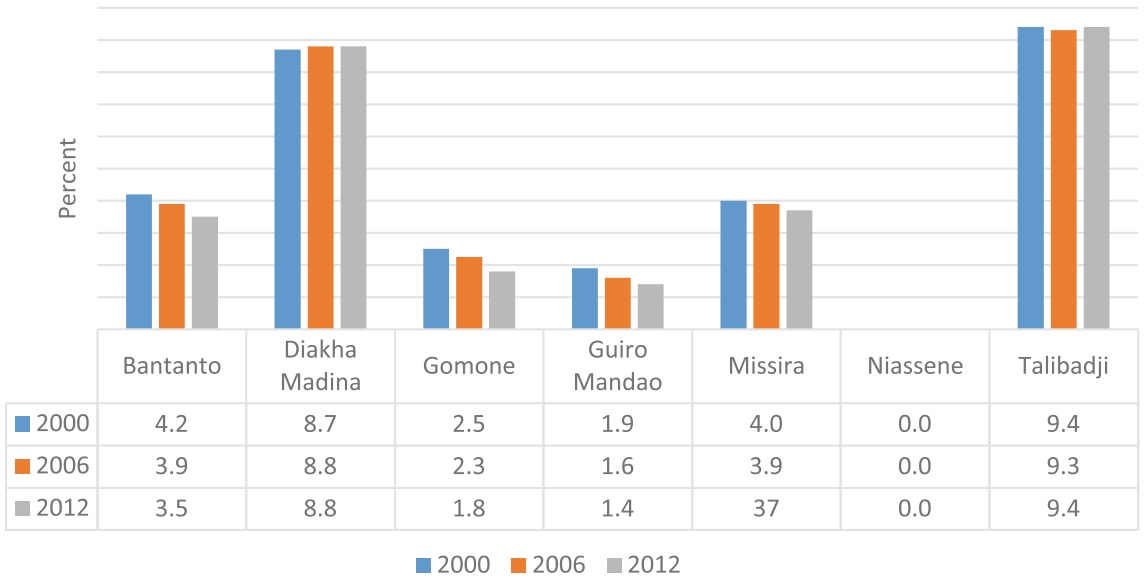

Fig. 19.10 Trend of forested area in case study villages. Source Focus Group Discussion 2014 


\section{Actions Taken to Address Declining Importance of Ecosystem Service}

In order to maintain or restore the quality of cropland, the most common approaches taken were fertility management, expansion of cropland area and control of livestock movement. Only Guiro Mandou community reported to have seen successful implementation of all three actions (Table 19.11). Limited production of manure and high cost of inorganic inputs were the major reasons behind failure of action to address declining soil fertility. Restriction of movement of animals was also not successful due to deep culture of feeding on crop residues by livestock keepers during dry season.

For forests, firewall, zoning, stricter enforcement of existing byelaws and enacting new ones were the most common approaches taken to address deforestation. Their implementation was successful in five of the seven communities

Table 19.11 Action taken to address decreasing ecosystem services of major biomes

\begin{tabular}{|c|c|c|c|c|c|c|}
\hline & \multirow[t]{2}{*}{ Cropland } & \multirow[t]{2}{*}{ Forest } & \multirow[t]{2}{*}{ Grazing lands } & \multicolumn{3}{|c|}{$\begin{array}{l}\text { Has it worked? Yes }=+ \text {, } \\
\text { No }=-\end{array}$} \\
\hline & & & & Cropland & Forests & $\begin{array}{l}\text { Grazing } \\
\text { land }\end{array}$ \\
\hline $\begin{array}{l}\text { Diakha } \\
\text { Madina }\end{array}$ & $\begin{array}{l}\text { Fertilizer } \\
\text { application }\end{array}$ & $\begin{array}{l}\text { Firewall, } \\
\text { collective } \\
\text { protection and } \\
\text { byelaws }\end{array}$ & $\begin{array}{l}\text { Firewalls, } \\
\text { collective action } \\
\text { to control bush } \\
\text { burning }\end{array}$ & - & + & + \\
\hline Missira & $\begin{array}{l}\text { ISFM, } \\
\text { rudimentary } \\
\text { dam }\end{array}$ & $\begin{array}{l}\text { Reduce forest } \\
\text { harvesting }\end{array}$ & $\begin{array}{l}\text { Increase advisory } \\
\text { services on better } \\
\text { pasture } \\
\text { management }\end{array}$ & - & + & + \\
\hline $\begin{array}{l}\text { Guiro } \\
\text { Mandou }\end{array}$ & $\begin{array}{l}\text { Zero grazing } \\
\text { animals, } \\
\text { cropland } \\
\text { expansion }\end{array}$ & $\begin{array}{l}\text { Firefighting } \\
\text { committee }\end{array}$ & $\begin{array}{l}\text { Improved } \\
\text { grassland } \\
\text { management }\end{array}$ & + & + & + \\
\hline Bantanto & $\begin{array}{l}\text { Use manure, } \\
\text { cropland } \\
\text { expansion }\end{array}$ & $\begin{array}{l}\text { Committee } \\
\text { against bush } \\
\text { fires, } \\
\text { enforcement of } \\
\text { zonation }\end{array}$ & $\begin{array}{l}\text { Firewalls, } \\
\text { committee } \\
\text { against cattle } \\
\text { theft }\end{array}$ & - & + & + \\
\hline Gomone & $\begin{array}{l}\text { Cropland } \\
\text { expansion, } \\
\text { ISFM }\end{array}$ & Byelaws, zoning & $\begin{array}{l}\text { Transhumance, } \\
\text { use of crop } \\
\text { residues }\end{array}$ & - & - & + \\
\hline Niassene & $\begin{array}{l}\text { Change crop } \\
\text { type, zero } \\
\text { grazing, } \\
\text { zoning }\end{array}$ & $\begin{array}{l}\text { Zoning, } \\
\text { promotion of } \\
\text { modern houses }\end{array}$ & & - & - & - \\
\hline Talibadji & $\begin{array}{l}\text { Manure, } \\
\text { control of } \\
\text { livestock } \\
\text { movement }\end{array}$ & Nothing done & $\begin{array}{l}\text { Use crop } \\
\text { residues, } \\
\text { common penning } \\
\text { area }\end{array}$ & - & + & + \\
\hline
\end{tabular}

Source Focus Group Discussion 2014 
suggesting that the collective action of enacting byelaws and enforcing them appear to be most effective. This is consistent with Nkonya et al. (2008) who observed greater compliance with byelaws enacted by local council than those enacted by higher legislative bodies. Likewise, collective action on community pasture management, committees against cattle theft and advisory services on improved pasture management were the most common approaches used and they worked in six of the seven communities.

A clear pattern is seen in the successful action to improve resource management. The cropland management approaches used are done at household level and remain hampered by resource scarcity of farmers. Most communities reported success in improving forest and grazing land biome largely through participatory involvement of the communities. This underscores the importance of the collective management and byelaws that tend to be more effective when enacted and enforced at community level the community. To illustrate the importance of community participation in decision making and collective management of resources, we give a case study of a successful participatory forestmanagement, which is being implemented under collaboration between communities surrounding the forest and the government. The case study illustrates the key features required for successful government collaboration with communities surrounding forests.

Initiated in 2006, Dankou Forest in the region of Kaffrine is implemented using participatory forest management approach. With an area of 10 ha, Dankou forest was replanted by the participating communities after it experienced complete deforestation. A total of 16 surrounding villages are involved in planning, monitoring and evaluation of the forestdevelopment. Additionally, the communities are responsible for protecting and managing the forest. The routine forest management activities include fire control and guarding against illegal forest product harvesting (Käser 2003; Gill 2013). The participating communities have enacted a number of byelaws and have formed committees to enforce them in collaboration with the department of water and forestry and the local government, which-according the Decentralization Act of 1996 - has the land administration mandate. To incentivize communities to participate in forest management, they are allowed to harvest firewood and other non-timber forest products but the harvesting is regulated to ensure it is sustainable. The net profit that communities have obtained in the past eight years is estimated to be US\$103, 580 and the cost of afforestation program during the same period was US\$49,560. Table 19.12 reveals a detailed overview of the afforestation and maintenance costs of Dankou forest.

Establishing the forest at the beginning is the largest share of the cost (Fig. 19.11). The protection, which involves pecuniary and non-pecuniary costs, is just around one third of the total cost.

However, of particular importance is the investment that the government put in information and awareness creation on CBFM. The major objectives of information and awareness creation are to build local capacity to sustainably manage forest resources and to educate community members on the importance of their participation in the CBFM. The information and awareness effort also involved discussion on sharing the benefits and the community responsibility of forest protection, 
Table 19.12 Cost of afforestation of 10 ha forest, Senegal

Fig. 19.11 Cost of protection of Dankou classified forest. Source Calculated using data obtained from development and sylvo-pastoral management plan of the Dankou classified forest

\begin{tabular}{l|c}
\hline Type of operation & Total cost (US\$) \\
\hline Establishment & 123.88 \\
\hline Setting boundary markers & 12.39 \\
\hline Establishing and maintaining plant nursery & 665.49 \\
\hline Planting material & 51.19 \\
\hline Transportation of plants & 102.38 \\
\hline Small planting material & 20.48 \\
\hline Fencing & 133.10 \\
\hline Digging holes & 133.10 \\
\hline Planting & \\
\hline Maintenance & 225.24 \\
\hline Maintenance & 22.52 \\
\hline Support and supervision & 45.97 \\
\hline Other & 1535.75
\end{tabular}

Source Calculated using data obtained from Development and sylvo-pastoral management plan of the Dankou classified forest

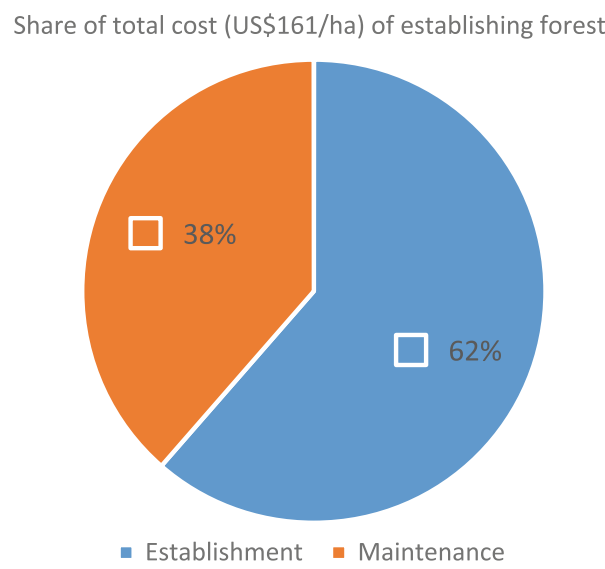

management, monitoring and evaluation and sustainable forest harvesting. Interestingly, the information and awareness creation was the largest cost item after the replanting and establishment activities ended in 2009, when trees reached biological maturity (Fig. 19.12). The information and awareness campaign might be the main driver of the long-run success of the project and could even help communities to realize the local and global ecosystem benefits of the forests. Additionally, by using the channels of the information campaign other integrated agro-forestry-pastoral activities were promoted, such as assisted natural regeneration of important tree species on farmland, cereal-legume intercropping, plant 


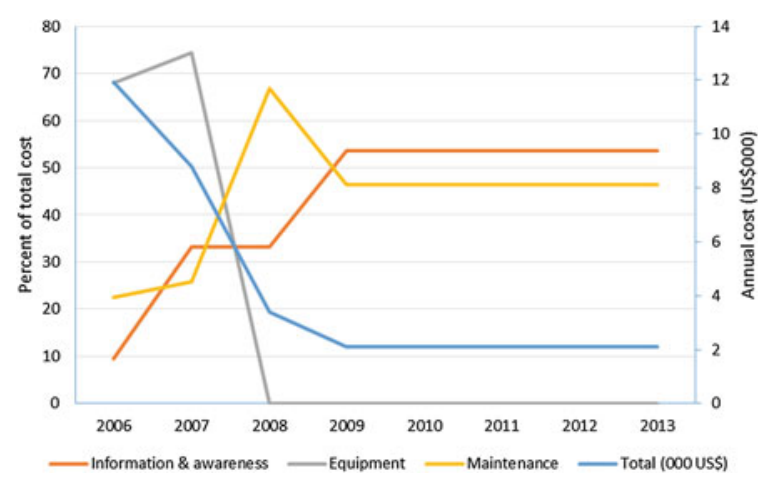

Fig. 19.12 Trend of cost of protection of Dankou classified forest. Source Calculated using data obtained from the development and sylvo-pastoral management plan of the Dankou classified forest

windbreaks, diversification of agricultural production, application manure from livestock and promoting intensive farming. As a result of the positive outcome of Dankou Forest, there were six new registrations for CBFM in the neighboring region of Kaolack within the Regional Forest Action Plan. This shows that the Dankou CBFM could be scaled-up.

\section{Groundtruthing Remote Sensing Data}

Groundtruthing was done by comparing the Le et al. (2014), Landsat and MODIS data with FGD perception about trend of land cover change. ${ }^{4}$ FGD results in villages which experienced land degradation showed high degree of agreement with Landsat and MODIS data results (Table 19.13). Bantanto, Gomone, and Niassene communities' assessment of land degradation was consistent with all three satellite data while only one community which remote sensing data showed improvement (Diakha Madina) was perceived by FGD participants to have improved (Table 19.13). As Anderson and Johnson (2014) argue, the inability of satellite data to capture specific type of land degradation is complemented by the its ability to reflect the reduced vegetative health of plants growing on saline soils, eroded soils and other forms of non-vegetative cover land degradation. However, the inability of satellite data to capture some form of land degradation is revealed in sites that experienced improvement. For example, FGD at Dakha Madina, observed a decrease in crop value due to soil erosion. There may, in fact, be a number of competing processes at work as increasing cropland area is causing deforestation, but regeneration of fallowed fields increases natural vegetation cover. Similarly the site has experienced water erosion and a perceived decrease in crop values but also reports an increased yields in recent years.

\footnotetext{
${ }^{4}$ For more details on the methodology, see Anderson and Johnson (2014).
} 
Table 19.13 Groundtruthing of satellite-derived data using FGD

\begin{tabular}{l|l|l|l|l|l}
\hline Site & $\begin{array}{l}\text { Bao Le } \\
\text { assessment }\end{array}$ & $\begin{array}{l}\text { FGD } \\
\text { assessment }\end{array}$ & $\begin{array}{l}\text { Change in } \\
\text { landsat NDVI }\end{array}$ & $\begin{array}{l}\text { MODIS Land } \\
\text { cover change }\end{array}$ & Agreement \\
\hline Talibdji & Improved & Degraded & Degraded & Improved & $2 / 4$ \\
\hline Niassene & Degraded & Degraded & Degraded & Degraded & $4 / 4$ \\
\hline Missira & Degraded & Degraded & Improved & Mixed & $2.5 / 4$ \\
\hline $\begin{array}{l}\text { Guiro Yoro } \\
\text { Mandou }\end{array}$ & Improved & Degraded & Degraded & Mixed & $2.5 / 4$ \\
\hline Gomone & Degraded & Degraded & Degraded & Degraded & $4 / 4$ \\
\hline $\begin{array}{l}\text { Diakha } \\
\text { Madina }\end{array}$ & Improved & Mixed & Improved & Improved & $3.5 / 4$ \\
\hline Bantanto & Degraded & Degraded & Degraded & Degraded & $4 / 4$ \\
\hline
\end{tabular}

Source Anderson and Johnson (2014)

Talibadji showed the lowest consistency, which could be due to MODIS land cover classes that dominate Talibadji have poor user accuracy (many below $50 \%$, i.e., misclassifications are likely (Friedl et al. 2010). The FGD, meanwhile, revealed that erosion has decreased yields and therefore the value of crops, which would not have shown up in the NDVI analysis.

\section{Drivers of Adoption of Sustainable Land Management Practices}

As expected physical capital endowment increases the propensity to adopt all types of SLM practices considered (Table 19.14). Surprisingly, farmers in the arid and semi-arid areas are more likely to adopt SLM practices than those in the humid areas. This could be due to the better soil fertility (e.g. high soil carbon) in the humid area that does not require significant soil improvement investment. Similar pattern has been observed in Nigeria where farmers in drier northern Nigeria apply more fertilizer and organic inputs than those in the humid southern zone (Nkonya et al. 2010).

Human capital endowment have ambiguous impact on adoption of SLM practices. While household size increases the probability to adopt ISFM and fertilizer, it reduces the propensity to adopt manure. Female managed plots are less likely to receive any of the three SLM practices while number of adult males increases the likelihood of using manure and fertilizer. These results are consistent with other studies which have shown that women-operated plots are less likely to use improved land management practices due to the resource constraints they face (Peterman et al. 2014).

Having non-farm income increases the likelihood to use manure and fertilizer but has no significant impact on using ISFM. This is consistent with Moussa et al. (2015) who observed similar results in Niger. The results underscore the synergistic role played that non-farm and farm activities play in rural economic activities.

Consistent with Boserupian theory (Boserup 1965), high population density increases the propensity to use ISFM. Market access increases the likelihood to use 
Table 19.14 Drivers of adoption of SLM practices in Senegal

\begin{tabular}{|c|c|c|c|}
\hline & Manure only & Fertilizer only & ISFM \\
\hline \multicolumn{4}{|l|}{ Human capital endowment } \\
\hline Household size & $-0.021 * * *$ & $0.022 * * *$ & $0.028^{* *}$ \\
\hline Female headed household & 0.05 & -0.21 & 0.154 \\
\hline Number adult females & $0.041 * *$ & $0.044 * *$ & -0.019 \\
\hline Number adult males & 0.012 & -0.025 & -0.016 \\
\hline Female Managed plot & $-0.529 * * *$ & $-0.410 * * *$ & $-0.290 *$ \\
\hline Has nonfarm income & $0.143 * * *$ & $0.161 * * *$ & -0.073 \\
\hline \multicolumn{4}{|l|}{ Physical capital endowment } \\
\hline TLU & $0.020 * * *$ & $-0.050 * * *$ & -0.014 \\
\hline Own radio & $0.122 * *$ & $0.157 * *$ & $0.388^{* * *}$ \\
\hline Own mobile phone & 0.086 & -0.017 & 0.107 \\
\hline Own bicycle & $0.361 * * *$ & 0.131 & $0.452 * *$ \\
\hline Plot area (ha) & $0.108 * * *$ & $0.185^{* * *}$ & $0.194 * * *$ \\
\hline Arid and semi arid (cf humid and subhumid) & $0.398 * * *$ & $0.328 * * *$ & $0.413^{*}$ \\
\hline \multicolumn{4}{|l|}{ Access to rural services } \\
\hline High population density (cf low density) & $-0.328 * * *$ & $0.186^{* *}$ & $0.825^{* * *}$ \\
\hline High market access (cf low market) & $1.262 * * *$ & $-1.424 * * *$ & $0.340^{* *}$ \\
\hline Use improved seed & -0.097 & $0.353 * * *$ & $0.465^{* * *}$ \\
\hline Received ag extension services & -0.34 & $-1.023 * * *$ & $-0.862 * *$ \\
\hline \multicolumn{4}{|l|}{ Land tenure/method of acquisition (cf customary) } \\
\hline Sharecropping & -0.284 & 0.454 & -0.768 \\
\hline Loaned & $-0.343 * * *$ & $0.348 * * *$ & 0.182 \\
\hline Leasehold & -0.005 & $1.385^{* * *}$ & $1.726 * * *$ \\
\hline Other method of land tenure & -0.075 & $0.834 * * *$ & $-13.246 * * *$ \\
\hline Constant & $-2.599 * * *$ & $-1.003 * * *$ & $-3.202 * * *$ \\
\hline
\end{tabular}

*statistically significant at $10 \%$;**tatistically significant at $5 \%$;***tatistically significant at $1 \%$

Source Agricultural survey (Enquête Agricole) (2011/12), Direction de l'analyse de la prevision et des statistiques (DAPS)

manure and ISFM but surprisingly reduces the propensity to use fertilizer. Consistent with Nkonya et al. (1997) farmers who use improved seeds are more likely to use fertilizer and ISFM. This demonstrates farmers' effort to increase returns to their investments by simultaneously adopting synergistic technologies. Access to extension services has either a negative or non-significant impact on SLM adoption - underlining the weak extension services in the country.

Farmers who hold their land under leasehold are more likely to use fertilizer and ISFM than those who acquired their land under customary tenure-inheritance. However, plots under customary tenure are more likely to receive ISFM than those under other types of land tenure. Similarly plots held under customary tenure are more likely to receive manure than those loaned. Overall, the results on land tenure and method of land acquisition are ambiguous and further research is required to draw robust results. 


\section{Conclusions and Policy Implications}

Senegal has invested significantly in agricultural and rural development and it is one of the countries with highest rural development infrastructure and access to agricultural extension services. Public expenditure on agriculture grew by $7 \%$ annually from 2003 to 2010, making Senegal one of the 13 SSA countries to achieve the Maputo Declaration target of spending at least $10 \%$ of government budget on agriculture. The country has also enjoyed robust political stability and democracy that has given investment confidence to both domestic and foreign investors. Despite these impressive achievements, the country is facing a major challenge of land degradation, which has contributed to the almost stagnant agricultural productivity. About $22.2 \%$ of Senegal's population of 13 million live in degraded areas. Groundthruthing of the remote sensing data used in this study showed that communities' assessment of land degradation was consistent with the satellite data while improvement measured by remote sensing was only confirmed by one community. Focus group discussion results also showed that communities perceived decreasing ecosystem services largely due to land degradation and climate change. This suggests greater reliability of remote sensing data showing land degradation but lower reliability for satellite data showing improvement.

Our study shows that the annual cost of land degradation on rice, millet and maize - which account for $45 \%$ of cropland area-is US103 million, or $2 \%$ of the country's GDP. The on-farm cost of grassland degradation is about 9 million or $0.1 \%$ of the GDP. The low cost of grassland degradation is a reflection of the low livestock productivity. This calls for the need to increase livestock productivity by addressing grassland degradation, improving the livestock genetic resources through breeding and pasture management. Such investment will have large returns given that the national and international demand for livestock products is increasing. Investment in improving livestock will also simultaneously address severe land degradation and achieve poverty reduction objectives.

Considering only local tangible benefits, the cost of land degradation due to LUCC is about US $\$ 0.412$ billion or $4 \%$ of the GDP. This shows the large cost of land degradation and the need for taking effective strategies to address this challenge. Returns to taking action against land degradation are high and investment in restoration of degraded lands will be of greater benefit to the rural poor who heavily depend on natural resources. The current rural development investments that Senegal has put in place provide great potential for successfully addressing land degradation. For example, the large number of agricultural extension agents from NGOs and other private providers creates an ideal environment for addressing the "unholy cross"-which portrays an inverse relationship between adoption rate and profitability of SLM practices. Extension messages promoting ISFM practices and strengthened public-private partnerships could help increase adoption of ISFM and other SLM practices. Having non-farm activities and higher market access increase the propensity to use SLM practices. Additionally physical endowment increases the likelihood to adopt SLM practices. These results underscore the importance of 
improving access to market and enhancing non-farm activities which appear to provide synergistic support to farm activities.

The success story of Dankou CBFM also offers lessons for addressing LUCC related land degradation in Senegal and other SSA countries. Strong local governments and community participation in natural resource management that was successfully implemented in the Dankou CBFM and the significant investment in awareness creation and information sharing offers an important lesson for building land users knowledge on ecosystem services and their capacity to sustainably manage natural resources.

Open Access This chapter is distributed under the terms of the Creative Commons Attribution Noncommercial License, which permits any noncommercial use, distribution, and reproduction in any medium, provided the original author(s) and source are credited.

\section{Appendix}

Policies related to land management.

\begin{tabular}{|c|c|c|c|c|}
\hline Period & $\begin{array}{l}\text { Title of taken } \\
\text { agricultural policy } \\
\text { measure }\end{array}$ & Content of the policy & $\begin{array}{l}\text { Expected impacts } \\
\text { on land }\end{array}$ & Real impacts on land \\
\hline \multirow[t]{6}{*}{1964} & \multirow[t]{6}{*}{$\begin{array}{l}\text { Law No. } 64-46 \text { of } \\
17 \text { June } 1964 \text { on the } \\
\text { national domain }\end{array}$} & $\begin{array}{l}\text { Abolition of } \\
\text { customary land } \\
\text { rights }\end{array}$ & $\begin{array}{l}\text { Repeal of customary } \\
\text { rules on land }\end{array}$ & $\begin{array}{l}\text { Insufficient law } \\
\text { enforcement }\end{array}$ \\
\hline & & $\begin{array}{l}\text { Integration into the } \\
\text { regime of national } \\
\text { domain of about } \\
95 \% \text { of the land of } \\
\text { the country }\end{array}$ & $\begin{array}{l}\text { Limitation of } \\
\text { private land } \\
\text { ownership }\end{array}$ & $\begin{array}{l}\text { Persistence of } \\
\text { customary practices }\end{array}$ \\
\hline & & \multirow{4}{*}{$\begin{array}{l}\text { The state now owns } \\
\text { land in the national } \\
\text { domain }\end{array}$} & $\begin{array}{l}\text { Prohibition of land } \\
\text { transaction }\end{array}$ & \multirow{4}{*}{$\begin{array}{l}\text { Tenure insecurity } \\
\text { unfavorable to } \\
\text { private investment }\end{array}$} \\
\hline & & & $\begin{array}{l}\text { Substitution of the } \\
\text { usage right to the } \\
\text { right of land } \\
\text { ownership with an } \\
\text { obligation of } \\
\text { development }\end{array}$ & \\
\hline & & & $\begin{array}{l}\text { Free access to land } \\
\text { (no tax is levied on } \\
\text { the occupation and } \\
\text { use of land in the } \\
\text { national domain) }\end{array}$ & \\
\hline & & & $\begin{array}{l}\text { Decentralization of } \\
\text { land management to } \\
\text { local communities } \\
\text { that are emanations } \\
\text { of populations }\end{array}$ & \\
\hline
\end{tabular}


(continued)

\begin{tabular}{|c|c|c|c|c|}
\hline Period & $\begin{array}{l}\text { Title of taken } \\
\text { agricultural policy } \\
\text { measure }\end{array}$ & Content of the policy & $\begin{array}{l}\text { Expected impacts } \\
\text { on land }\end{array}$ & Real impacts on land \\
\hline \multirow[t]{4}{*}{1995} & \multirow{4}{*}{$\begin{array}{l}\text { Ratification by } \\
\text { Senegal of the } \\
\text { United Nations } \\
\text { Convention to } \\
\text { Combat } \\
\text { Desertification } \\
\text { (UNCCD) }\end{array}$} & \multirow{4}{*}{$\begin{array}{l}\text { Creation of a legal } \\
\text { and institutional } \\
\text { environment for the } \\
\text { full participation of } \\
\text { populations and } \\
\text { local communities to } \\
\text { all action against } \\
\text { desertification and } \\
\text { the adverse effects of } \\
\text { drought }\end{array}$} & $\begin{array}{l}\text { Prevent and/or } \\
\text { reduce land } \\
\text { degradation }\end{array}$ & $\begin{array}{l}\text { Poor integration of } \\
\text { priorities for fight } \\
\text { against } \\
\text { desertification in } \\
\text { national budgets }\end{array}$ \\
\hline & & & \multirow[t]{3}{*}{$\begin{array}{l}\text { Restore potentially } \\
\text { degraded land and } \\
\text { desertified land }\end{array}$} & $\begin{array}{l}\text { Weakness funding } \\
\text { allocated to the fight } \\
\text { against } \\
\text { desertification }\end{array}$ \\
\hline & & & & $\begin{array}{l}\text { Weak harmonization } \\
\text { of interventions }\end{array}$ \\
\hline & & & & $\begin{array}{l}\text { Lack of relevant } \\
\text { indicators for } \\
\text { monitoring activities } \\
\text { against } \\
\text { desertification... } \\
\end{array}$ \\
\hline \multirow[t]{4}{*}{1996} & \multirow[t]{4}{*}{$\begin{array}{l}\text { Laws no. } 96-06 \text { and } \\
96-07 \text { of } 22 \text { May } \\
1996 \text { on } \\
\text { decentralization }\end{array}$} & $\begin{array}{l}\text { New areas of } \\
\text { competence of the } \\
\text { State, including } \\
\text { natural resources } \\
\text { transferred to local } \\
\text { communities }\end{array}$ & $\begin{array}{l}\text { Transfer of new } \\
\text { land powers to local } \\
\text { authorities }\end{array}$ & $\begin{array}{l}\text { On the lands of } \\
\text { interest for economic } \\
\text { and social } \\
\text { development, } \\
\text { reduction of central } \\
\text { state land powers for } \\
\text { the benefit of local } \\
\text { communities }\end{array}$ \\
\hline & & \multirow{3}{*}{$\begin{array}{l}\text { Possibility of the } \\
\text { State to transfer all } \\
\text { or part of its } \\
\text { prerogatives on } \\
\text { national domain } \\
\text { land, to local } \\
\text { communities }\end{array}$} & \multirow[t]{3}{*}{$\begin{array}{l}\text { Facilitate access to } \\
\text { land for private } \\
\text { investors }\end{array}$} & $\begin{array}{l}\text { Inadequate } \\
\text { implementation of } \\
\text { transferred due } \\
\text { competencies: }\end{array}$ \\
\hline & & & & $\begin{array}{l}\text { - Lack of human } \\
\text { resources in local } \\
\text { communities }\end{array}$ \\
\hline & & & & $\begin{array}{l}\text { - Weakness of } \\
\text { instruments of land } \\
\text { management (land } \\
\text { registry, land etc. } \\
\text { development plans.) }\end{array}$ \\
\hline \multirow[t]{4}{*}{2004} & \multirow[t]{4}{*}{$\begin{array}{l}\text { Law of } \\
\text { Agro-Silvo-Pastoral } \\
\text { Orientation }\end{array}$} & $\begin{array}{l}\text { Improvement of } \\
\text { living conditions in } \\
\text { rural areas }\end{array}$ & $\begin{array}{l}\text { Modernization of } \\
\text { the family farm }\end{array}$ & $\begin{array}{l}\text { Delay in the } \\
\text { publication of } \\
\text { implementing } \\
\text { decrees }\end{array}$ \\
\hline & & $\begin{array}{l}\text { Environmental } \\
\text { protection and } \\
\text { sustainable land } \\
\text { management }\end{array}$ & \multirow[t]{3}{*}{$\begin{array}{l}\text { Securing the } \\
\text { productive base by } \\
\text { promoting private } \\
\text { investment }\end{array}$} & $\begin{array}{l}\text { The development of } \\
\text { agro-business }\end{array}$ \\
\hline & & \multirow{2}{*}{$\begin{array}{l}\text { Incentives for private } \\
\text { investment in } \\
\text { agriculture and rural } \\
\text { areas }\end{array}$} & & $\begin{array}{l}\text { Trend of land } \\
\text { grabbing by foreign } \\
\text { capital }\end{array}$ \\
\hline & & & & Deforestation \\
\hline
\end{tabular}


(continued)

\begin{tabular}{l|l|l|l|l}
\hline Period & $\begin{array}{l}\text { Title of taken } \\
\text { agricultural policy } \\
\text { measure }\end{array}$ & Content of the policy & $\begin{array}{l}\text { Expected impacts } \\
\text { on land }\end{array}$ & Real impacts on land \\
\hline 2004 & $\begin{array}{l}\text { Decree } \\
\text { No. 2004-802 of } 28 \\
\text { June 2004 } \\
\text { establishing the } \\
\text { National Institute of } \\
\text { Pedology of Senegal }\end{array}$ & $\begin{array}{l}\text { Creation of a } \\
\text { national structure to } \\
\text { coordinate } \\
\text { sustainable land } \\
\text { management in } \\
\text { Senegal }\end{array}$ & $\begin{array}{l}\text { Improve knowledge } \\
\text { on soil resources of } \\
\text { the country }\end{array}$ & $\begin{array}{l}\text { Increased awareness } \\
\text { of stakeholders in the } \\
\text { sustainable land } \\
\text { management }\end{array}$ \\
\cline { 3 - 5 } & $\begin{array}{l}\text { Develop } \\
\text { rehabilitation } \\
\text { activities and land } \\
\text { reclamation }\end{array}$ & $\begin{array}{l}\text { Strategic planning of } \\
\text { investments in } \\
\text { sustainable land } \\
\text { management }\end{array}$ \\
\cline { 3 - 5 } & $\begin{array}{l}\text { Promoting regional } \\
\text { and international } \\
\text { cooperation in the } \\
\text { field of soil science }\end{array}$ & $\begin{array}{l}\text { Establishment of a } \\
\text { technical package of } \\
\text { proven SLM in } \\
\text { different } \\
\text { pedo-climatic zones } \\
\text { of the country }\end{array}$ \\
\hline
\end{tabular}

\section{References}

Agricultural survey (Enquête Agricole). (2011/12). Direction de l'analyse de la prevision et des statistiques (DAPS). Raw data.

Agriculture for Impact. (2014). Small and growing entrepreneurship in African agriculture. A Montpellier Panel Report.

Anderson, W., \& Johnson, T. (2014). Evaluating global land degradation mapping using ground-based measurements and remote sensing. In E. Nkonya, A. Mirzabaev \& J. von Braun (Eds.), Global assessment of the economics of land degradation and improvement. Springer (Forthcoming).

Bagayoko, M., Mason, S. C., Traore, S., \& Eskridge, K. M. (1996). Pearl millet/cowpea cropping system yields and soil nutrient levels. Afr Crop Sci J, 4, 453-462.

Beintema, N., \& Stads, G.J. (2011). African agricultural R\&D in the new millennium. Progress for some, challenges for many. International Food Policy Research Institute. Food Policy Report 24.

Benin, S., \& Yu, B. (2012). Complying the Maputo declaration target: Trends in public agricultural expenditures and implications for pursuit of optimal allocation of public agricultural spending. ReSAKSS Annual Trends and Outlook Report 2012. International Food Policy Research Institute (IFPRI).

Boserup, E. (1965). The conditions of agricultural growth. London: Allen and Unwin.

Centre de Suivi Ecologique. (2013). Annuaire sur l'environnement et les resources naturelles du Sénégal (3rd edn).

DAT/USAID/RSI. (1985). Mapping and remote sensing of the resources of the Republic of Senegal-A study of the geology, hydrology, soils, vegetation and land use potential, Brookings, South Dakota.

Davis, K., Nkonya, E., Kato, E., Mekonnen, D. A., Odendo, M., \& Miiro, R. (2010). Impact of farmer field schools on agricultural productivity and poverty in East Africa. International Food Policy Research Institute.

Delmas, R.A., Loudjani, P., Podaire, A., \& Menaut, J. (1991). Biomass burning in Africa: An assessment of annually burned biomass. In S. J. Levine (Ed.), Global biomass burning. Atmospheric, climatic and biospheric implications (pp. 126-132). Cambridge, Massachusetts: The MIT Press. 
Directorate of Agriculture. (2001). The cultivation and production of millet and sorghum in Senegal: Diagnostic assessment and perspectives. Dakar.

DPS (Direction de la Prévision et de la Statistique). (2004). Deuxième Enquête Sénégalaise Auprès des Ménages (ESAM-II), 2004, Dakar, rapport, p. 260.

FAO. (2005). Senegal livestock brief. http://www.fao.org/ag/againfo/resources/en/publications/ sector_briefs/lsb_SEN.pdf. Accessed 3 Aug 2014.

FAO. (2011). State of the world's forests 2011. Rome: Italy.

FAOSTAT. (2014). Online agricultural database. http://faostat3.fao.org/faostat-gateway/go/to/ home/E. Accessed 2 Sept 2014.

Friedl, M., Sulla-Menashe, D., Tan, B., Schneider, A., Ramankutty, N., Sibley, A., \& Huang, X. (2010). MODIS global land cover: Algorithm refinements and characterization of new datasets. Remote Sensing of Environment, 114(1), 168-182.

Gijsman, A. J., Hoogenboom, G., Parton, W. J., \& Kerridge, P. C. (2002). Modifying DSSAT crop models for low-input agricultural systems using a soil organic matter-residue module from CENTURY. Agronomy Journal, 94(3), 462-474.

Gill, P. (2013). Working with local people to identify tree services, deforestation trends, and strategies to combat deforestation: A case study from Senegal's Peanut Basin. Thesis of Master Forest Resources: Washington University.

Guèye, M. (1992). Rapports d'activités analytiques 1989. Tambacounda: ISRA. http://depts. washington.edu/sefspcmi/wordpress/wp-content/uploads/2014/07/Gill-Final-paper1.pdf. Accessed 14 Sept 2014.

Henao, J., \& Baanante, C. (2006). Agricultural production and soil nutrient mining in Africa: Implications for resource conservation and policy development. Technical Bulletin IFDC T-72.

Inglehart, R., \& Welzel, C. (2005). Modernization, cultural change, and democracy: The human development sequence. Cambridge University Press, $333 \mathrm{p}$.

INP. (2012). Cadre National d'Investissement Strategique pour la Gestion Durable des Terres (CNIS/GDT). Dakar: Rapport Final.

Käser, M. (2003). Perception of the forest as a "Green Bank" evolved among rural population in the test zone of Dankou, Sénégal. Presented at the Tropentag 2003. Göttingen.

Kearney, J. (2010). Food consumption trends and drivers. Philosophical Transactions of the Royal Society B, 365, 2793-2807.

Le, Q. B., Nkonya, E. \& Mirzabaev, A. (2014). Biomass productivity-based mapping of global land degradation hotspots. ZEF-Discussion Papers on Development Policy No. 193. University of Bonn.

Moussa, B., Nkonya, E., Meyer, S., Kato,E., Johnson, T., \& Hawkins, J. (2015). Economics of land degradation and improvement in Niger. In E. Nkonya, A. Mirzabaev \& J. von Braun (Eds.), Economics of Land Degradation and Improvement - A Global Assessment for Sustainable Development. Springer (This volume).

Nandwa, S., \& Bekunda, M. A. (1998). Research on nutrient flows and balances in East and Southern Africa: State-of-the-art. Agriculture, ecosystems \& environment, 71(1), 5-18.

Ndione, Y. C. (2009). Impact des politiques agricoles sur la sécurité alimentaire au Sénégal. Mémoire de maîtrise: Universite Cheikh Anta Diop de Dakar.

Ndiaye, J. P. (1999). Recapitalization of phosphate reserves of Senegal soils: interest and limits. ISRA (Institut sénégalais de recherches agricoles)

Nkonya, E., Schroeder, T., \& Norman, D. W. (1997). Factors affecting adoption of improved maize seed \& fertilizer in Northern Tanzania. Journal of Agricultural Economics, 48, 1-12.

Nkonya, E., Pender, J., \& Kato, E. (2008). Who knows who cares? Determinants of enactment, awareness and compliance with community natural resource management regulations in Uganda. Environment and Development Economics, 13(1), 79-109.

Nkonya, E., Phillip, D., Mogues, T., Pender, J., \& Kato, E. (2010). From the Ground up: Impact of a pro-poor community driven development project in Nigeria (p. 93). Washington DC: International Food Policy Research Institute Research Monograph.

Nkonya, E., Anderson, W., Kato, E., Koo, J., Mirzabaev, A., von Braun, J., \& Meyer, S. (2015). Global cost of land degradation. Springer (chapter 6). 
Peterman, A., Behrman, J. A., \& Quisumbing, A. R. (2014). A review of empirical evidence on gender differences in nonland agricultural inputs, technology, and services in developing countries. In A. R. Quisumbing, R. Meinzen-Dick, T.L. Raney, A. Croppenstedt, J.A. Behrman \& A. Peterman (Eds.), Gender in Agriculture (pp. 145-186). Netherlands: Springer.

Post, J., \& Snel, M. (2003). The impact of decentralised forest management on charcoal production practices in Eastern Senegal. Geoforum, 34(1), 85-98.

Resnick, D. (2013). The political economy of food price policy in Senegal. Policy Brief No. 7. UNU-WIDER. Helsinki.

Savadogo, P., Sawadogo, L., \& Tiveau, D. (2007). Effects of grazing intensity and prescribed fire on soil physical and hydrological properties and pasture yield in the savanna woodlands of Burkina Faso agriculture. Ecosystems and Environment, 118(1-4), 80-92.

Stads, G. J., \& Sène, L. (2011). Private-sector agricultural research and innovation in Senegal. Recent Policy, Investment, and Capacity Trends. http://www.ifpri.org/sites/default/files/ publications/senegal-ps-note-full.pdf. Accessed 3 Aug 2014.

Vanlauwe, B., \& Giller, K. E. (2006). Popular myths around soil fertility management in sub-Saharan Africa. Agriculture, Ecosystems \& Environment, 116, 34-46.

Vlek, P., Rodríguez-Kuhl, G., \& Sommer, R. (2004). Energy use and $\mathrm{CO}_{2}$ production in tropical agriculture and means and strategies for reduction or mitigation. Environment, Development and Sustainability, 6, 213-233.

World Bank. (2008). Senegal - country environmental analysis. Report No. 48804-SN. Sustainable Development Department Africa Region. Washington.

World Bank. (2012). Agriculture and rural development data. http://data.worldbank.org/topic/ agriculture-and-rural-development. Accessed 13 Jan 2015.

World Bank. (2013). Senegal country at a glance. Available at http://www.worldbank.org/en/ country/senegal. Accessed 13 Jan 2015. 